\title{
¿On the Seasonal Cycles Observed at the Continental Slope of the Eastern Eurasian Basin of the Arctic Ocean
}

\author{
Till M. BAumann,, a,b IgOR V. Polyakov, ${ }^{\mathrm{a}, \mathrm{b}}$ ANDrey V. PNyushKov, ${ }^{\mathrm{a}}$ Robert Rember, ${ }^{\mathrm{a}}$ \\ Vladimir V. IVANov, ${ }^{\mathrm{c}, \mathrm{d}, \mathrm{e}}$ MATTHEw B. Alkire, ${ }^{\mathrm{f}}$ Ilona GoszCZKO, ${ }^{\mathrm{g}}$ AND EDDY C. CARMACK ${ }^{\mathrm{h}}$ \\ ${ }^{a}$ International Arctic Research Center, University of Alaska Fairbanks, Fairbanks, Alaska \\ ${ }^{\mathrm{b}}$ College of Natural Science and Mathematics, University of Alaska Fairbanks, Fairbanks, Alaska \\ ${ }^{\mathrm{c}}$ Moscow State University, Moscow, Russia \\ ${ }^{\mathrm{d}}$ Hydrometeorological Center of Russia, Moscow, Russia \\ ${ }^{\mathrm{e}}$ Arctic and Antarctic Research Institute, St. Petersburg, Russia \\ ${ }^{\mathrm{f}}$ Polar Science Center, Applied Physics Laboratory, University of Washington, Seattle, Washington \\ ${ }^{\mathrm{g}}$ Institute of Oceanology, Polish Academy of Sciences, Sopot, Poland \\ ${ }^{\mathrm{h}}$ Institute of Ocean Sciences, Fisheries and Oceans Canada, Sidney, British Columbia, Canada
}

(Manuscript received 17 August 2017, in final form 23 April 2018)

\begin{abstract}
The Eurasian Basin (EB) of the Arctic Ocean is subject to substantial seasonality. We here use data collected between 2013 and 2015 from six moorings across the continental slope in the eastern EB and identify three domains, each with its own unique seasonal cycle: 1$)$ The upper ocean $(<100 \mathrm{~m})$, with seasonal temperature and salinity differences of $\Delta \theta=0.16^{\circ} \mathrm{C}$ and $\Delta S=0.17$, is chiefly driven by the seasonal sea ice cycle. 2) The upperslope domain is characterized by the influence of a hydrographic front that spans the water column around the $\sim 750-\mathrm{m}$ isobath. The domain features a strong temperature and moderate salinity seasonality $\left(\Delta \theta=1.4^{\circ} \mathrm{C}\right.$; $\Delta S=0.06$ ), which is traceable down to $\sim 600-\mathrm{m}$ depth. Probable cause of this signal is a combination of along-slope advection of signals by the Arctic Circumpolar Boundary Current, local wind-driven upwelling, and a cross-slope shift of the front. 3) The lower-slope domain, located offshore of the front, with seasonality in temperature and salinity mainly confined to the halocline $\left(\Delta \theta=0.83^{\circ} \mathrm{C} ; \Delta S=0.11 ; \sim 100-200 \mathrm{~m}\right)$. This seasonal cycle can be explained by a vertical isopycnal displacement $(\Delta Z \sim 36 \mathrm{~m})$, arguably as a baroclinic response to sea level changes. Available long-term oceanographic records indicate a recent amplification of the seasonal cycle within the halocline layer, possibly associated with the erosion of the halocline. This reduces the halocline's ability to isolate the ocean surface layer and sea ice from the underlying Atlantic Water heat with direct implications for the evolution of Arctic sea ice cover and climate.
\end{abstract}

\section{Hydrography of the eastern Eurasian Basin region}

\section{a. General overview}

The eastern Eurasian Basin (EB) of the Arctic Ocean comprises the Nansen Basin (NB) and Amundsen Basin (AB) east of Severnaya Zemlya $\left(\sim 95^{\circ} \mathrm{E}\right)$ (Fig. 1). The focal area of this study is the continental slope descending from the shallow Laptev Sea shelf to the abyssal

¿ Denotes content that is immediately available upon publication as open access.

Corresponding author: Till M. Baumann, tmbaumann@ alaska.edu plain at approximately $125^{\circ} \mathrm{E}$. We will refer to this as the eastern EB continental slope. The water column in the eastern EB is characterized by a $\sim 20-50$-m-thick surface mixed layer (SML) overlaying the halocline, which is divided into the cold halocline layer (CHL; 50-100 m), distinguished by homogeneous near-freezing temperatures, and the lower halocline waters (LHW; $\sim 100$ $200 \mathrm{~m}$ ) with increasing temperature and salinity with depth (e.g., Rudels et al. 1991). The relatively warm $\left(>0^{\circ} \mathrm{C}\right)$ Atlantic Water $(\mathrm{AW})$ resides at intermediate depths below the halocline ( $200-1000 \mathrm{~m})$ (Fig. 2). Strong vertical salinity (and thus density) gradients in the halocline shield the SML and sea ice from the AW heat (e.g., Aagaard et al. 1981; Rudels et al. 1996). However, this insulating property may be compromised locally by storms and ocean dynamics (Polyakov et al. 2013). In 


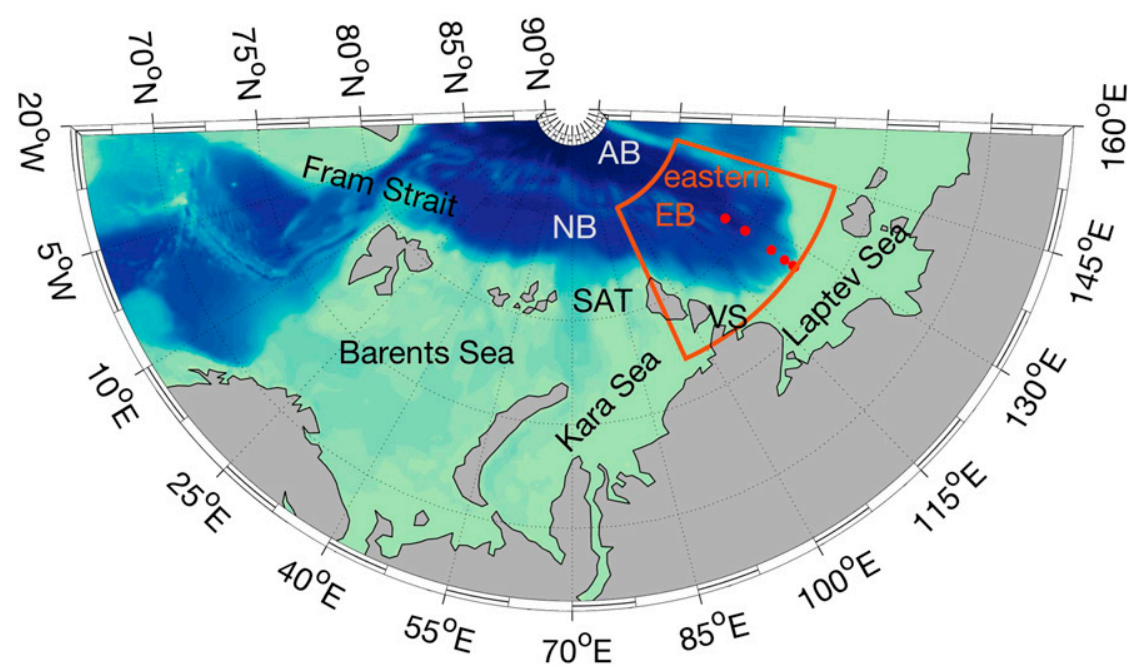

FIG. 1. Topographic map of the Atlantic side of the Arctic Ocean with the eastern EB outlined in orange. Red dots indicate positions of the moorings used in this study.

recent years, a weakening of the halocline in the eastern EB has led to enhanced vertical heat fluxes through the halocline layer with direct effects on sea ice formation (Polyakov et al. 2017).

The hydrography in the eastern EB continental slope region is strongly affected by the Arctic Circumpolar Boundary Current (ACBC). AW enters the Arctic Ocean through the Fram Strait and the Barents Sea and is carried by the ACBC cyclonically along the continental margins and ridges of the Arctic Ocean (Timofeev 1960; Coachman and Barnes 1963; Aagaard 1989; Rudels et al. 1994). The 2013-15 total transport within the ACBC amounts to $5.1 \pm 0.1 \mathrm{~Sv}\left(1 \mathrm{~Sv} \equiv 10^{6}\right.$ $\mathrm{m}^{3} \mathrm{~s}^{-1}$ ) at the Laptev Sea continental slope (Pnyushkov et al. 2018). The transport as well as the thermohaline properties of the ACBC are subject to substantial spatiotemporal fluctuations [see Pnyushkov et al. (2015) for detailed discussion].

\section{b. Hydrographic front along the continental slope}

The relatively warm and salty AW contrasts the abundant colder and fresher Arctic shelf water masses. Resulting horizontal property gradients form a hydrographic front that is observed along the AW pathways following the continental slope of the EB. Dmitrenko et al. (2014) reported a pronounced front at the eastern flank of the St. Anna Trough (SAT) in 1996 and in 2008-10, which extended throughout the entire water column with a horizontal density gradient between 0.0009 and $0.0022 \mathrm{~kg} \mathrm{~m}^{-3} \mathrm{~km}^{-1}$. Similarly, in the Laptev Sea, Bauch et al. (2014) observed the front at the continental slope, separating shelf waters, continental slope waters, and basin waters. Bauch et al. (2014) hypothesized that the front is maintained by lateral advection of water masses within the ACBC.

\section{c. Seasonal cycle in the eastern EB}

The seasonal cycle has long been recognized as one of the dominant modes of variability in the Arctic Ocean (e.g., Polyakov 1999). Historical data from averaged profiles taken during the 1950s-80s spanning the eastern EB region show a distinct seasonal signal exhibited by a warmer and fresher SML during summer and colder and saltier SML in winter, whereas in the lower halocline and upper AW layer, temperatures are lower in summer (Fig. 2).

Data availability remains the major limitation for detailed analysis of seasonality in the continental slope region. The few existing long-term mooring observations generally lack the desired spatial resolution, whereas summertime hydrographic sections with high spatial resolution provide only snapshots that cannot be used to document seasonality. Consequently, models have been employed to overcome these shortcomings. For example, in a study combining observations and modeling, Polyakov et al. (1999) analyzed pan-Arctic seasonality under different large-scale atmospheric circulation regimes. For the EB, they found model-derived upper-ocean $(0-50 \mathrm{~m})$ seasonal temperature and salinity changes of $0.015^{\circ} \mathrm{C}$ and 0.2 , respectively, for anticyclonic regimes and changes of $0.09^{\circ} \mathrm{C}$ and 0.55 for cyclonic regimes. In another effort, using model simulations supported by moored observations, Lique and Steele (2012) analyzed the propagation of the seasonal cycle of the AW core temperature, defined as the highest temperature in the profile above the $1500-\mathrm{m}$ isobath, along the 


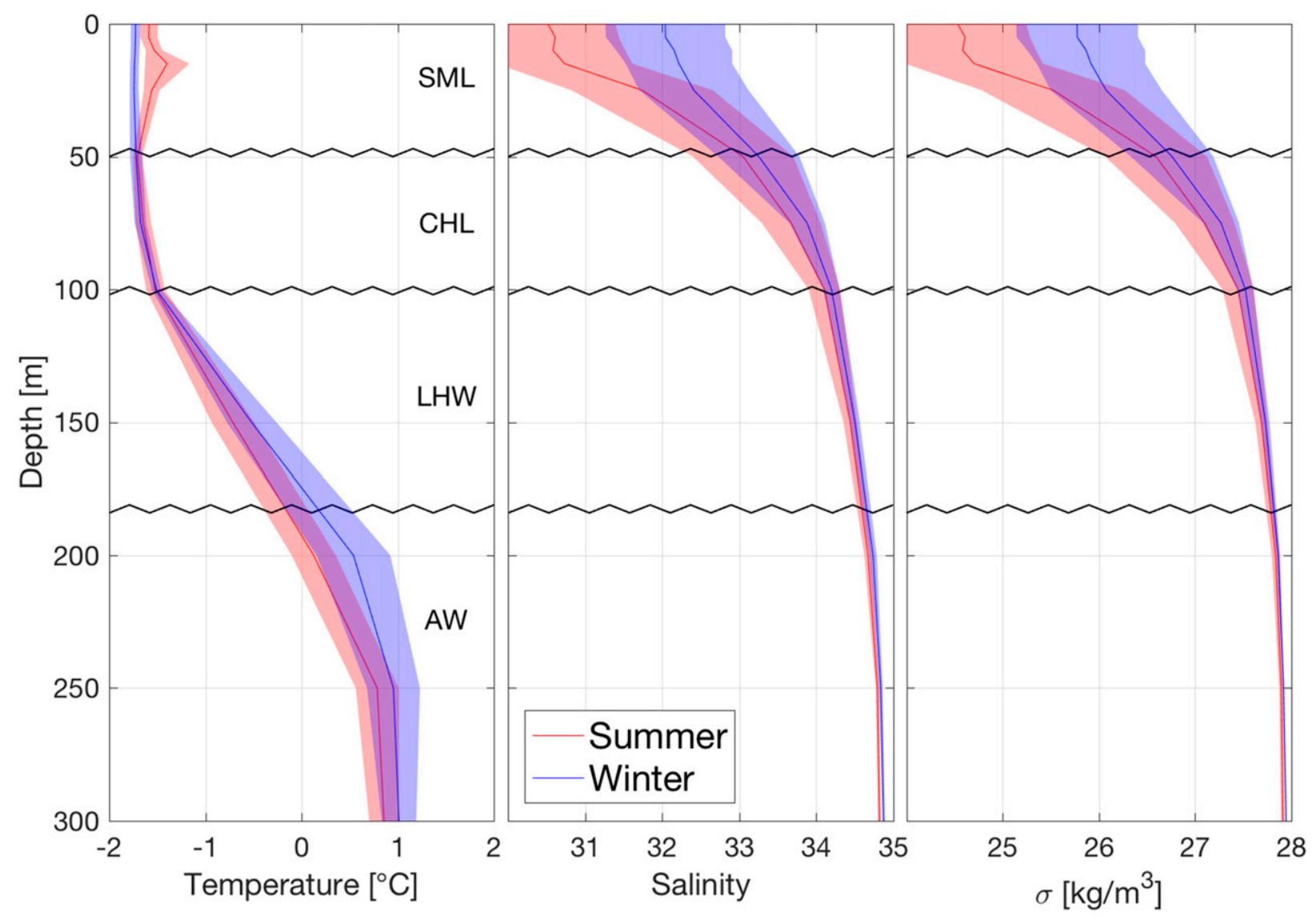

FIG. 2. Summer and winter temperature, salinity, and density $(\sigma)$ profiles from the Environmental Working Group Joint U.S.-Russian Atlas of the Arctic Ocean (see section 2 for description) averaged over the eastern EB region $\left(77^{\circ}-85^{\circ} \mathrm{N}, 95^{\circ}-145^{\circ} \mathrm{E}\right)$ from the 1950 s to the 1980s (shading is the standard deviation). Zigzag lines indicate approximate boundaries of the different layers: SML, CHL, LHW, and AW.

continental slope from the Fram Strait through the eastern EB. They found that the substantial $\left(>2^{\circ} \mathrm{C}\right)$ seasonal cycle of AW temperature observed in the Fram Strait is advected by the ACBC. By the time the signal reaches the eastern $\mathrm{EB}$, its amplitude decreased to $\sim 0.1^{\circ} \mathrm{C}$. This value was derived under the assumption that the AW closely follows the $1500-\mathrm{m}$ isobath. However, Pnyushkov et al. (2015) found that, in the eastern $\mathrm{EB}$, the $\mathrm{AW}$ temperature core was located substantially further offshore, around the 3000-m isobath, and that at times it split into two separate cores located over the 3000- and 3500-m isobaths. Long-term observations within the halocline $(\sim 150 \mathrm{~m})$ collected using moorings deployed at the $2700-\mathrm{m}$ isobath on the eastern EB slope suggest that local seasonal temperature changes increased from $0.25^{\circ} \mathrm{C}$ in 2004-07 (Dmitrenko et al. 2009) to $\sim 1^{\circ} \mathrm{C}$ in 2013-15 (Polyakov et al. 2017, their Fig. 2c).

Here, we use a two-year-long dataset spanning the water column down to $\sim 700 \mathrm{~m}$ at six locations across the
EB continental slope (section 2; Fig. 3) to identify hydrographic seasonal cycles in this region (section 3 ) and discuss likely drivers (section 4).

\section{Data and methods}

The central dataset used in this study consists of moored observations obtained within the Nansen and Amundsen Basin Observational System (NABOS) project. An array of six moorings $\left(\mathrm{M} 1_{1}-\mathrm{M} 1_{6}\right)$ spanning along the $125^{\circ} \mathrm{E}$ meridian from just offshore of the Laptev Sea shelf $\left(\sim 77^{\circ} \mathrm{N} ; 250\right.$-m water depth) to the abyssal plain $\left(\sim 81^{\circ} \mathrm{N} ; 3900-\mathrm{m}\right.$ depth) was deployed for two years from September 2013 to September 2015 (Fig. 3). All moorings were designed to carry out conductivity-temperature-depth (CTD), as well as velocity measurements. For the $\mathrm{M} 1_{1}$ and $\mathrm{M} 1_{4}$ moorings, CTD observations were collected at up to six discrete depths using SeaBird SBE 37 MicroCATs. All other moorings were equipped with McLane moored profilers 


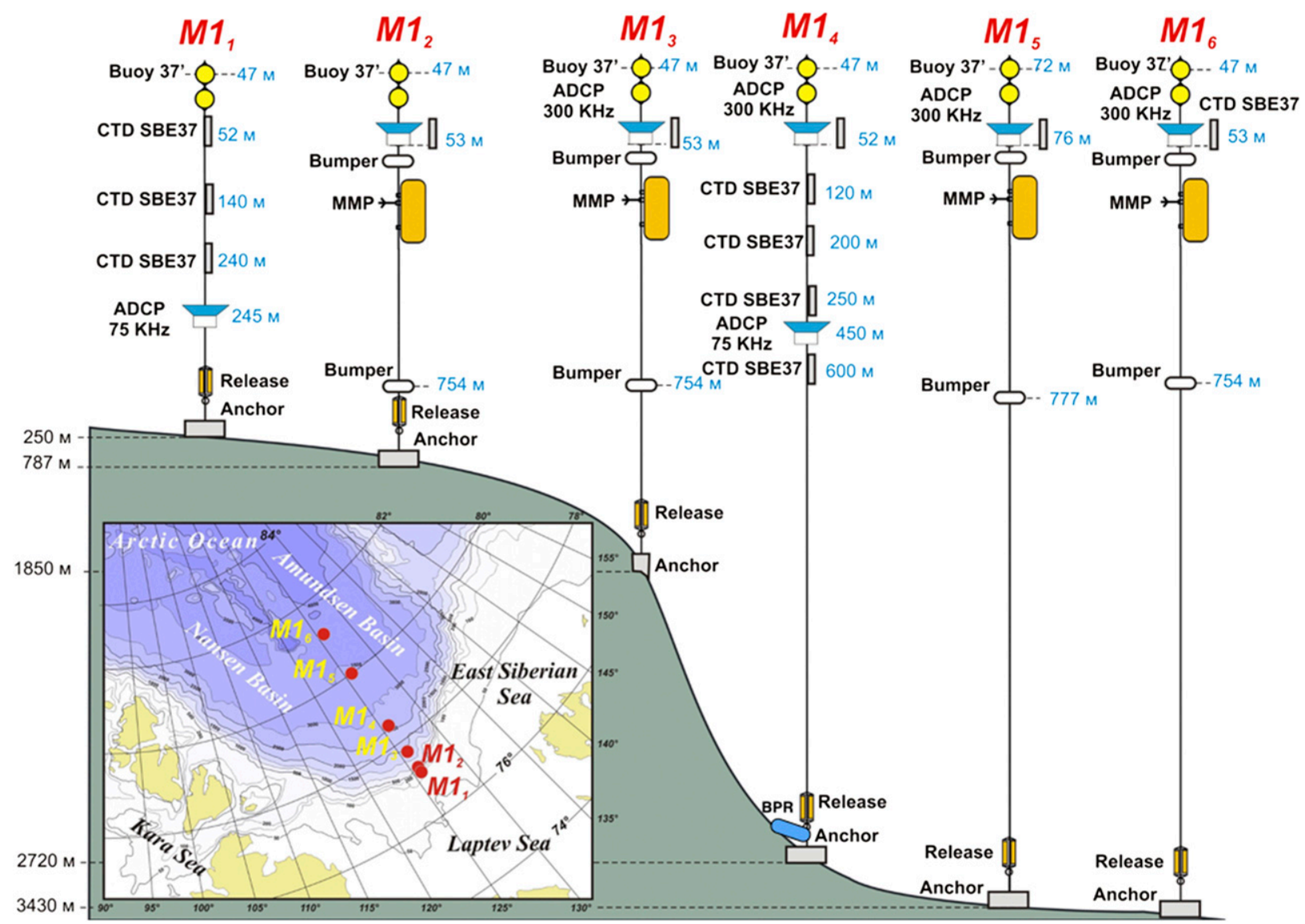

FIG. 3. Schematics (not to scale) and locations (insert) of six moorings deployed in the eastern EB along the $125^{\circ} \mathrm{E}$ in $2013-15$ (adapted from Pnyushkov et al. 2018).

(MMPs) that provided CTD and velocity profiles every other day between 50- and 750-m depth (vertical resolution of $\sim 25 \mathrm{~cm}$ ). The MMPs were equipped with highresolution $\left(<0.01 \mathrm{~cm} \mathrm{~s}^{-1}\right.$; error: $\left.\sim 1 \% \pm 0.5 \mathrm{~cm} \mathrm{~s}^{-1}\right)$ Falmouth Scientific Inc. (FSI) acoustic current meters and SBE 52-MP CTD sensors (expected accuracies: $0.0003 \mathrm{~S} \mathrm{~m}^{-1}, 0.002^{\circ} \mathrm{C}$, and $0.1 \%$ of full pressure range). All sensors were calibrated by the manufacturer before deployment in 2013. Upon recovery, the raw MMP data were processed using Woods Hole Oceanographic Institution (WHOI) software, which involved averaging the raw data over 2-dbar pressure bins. The MicroCATs were either sent back to the manufacturer for calibration or, if scheduled for immediate redeployment, were directly calibrated against the ship-based SBE 911plus sensor with expected accuracies of $0.0003 \mathrm{~S} \mathrm{~m}^{-1}$ and $0.005^{\circ} \mathrm{C}$ for conductivity and temperature, respectively.

Current velocities for the upper $\sim 250 \mathrm{~m}$ at moorings $\mathrm{M} 1_{1}$ and $\mathrm{M} 1_{4}$ were obtained by $75-\mathrm{kHz}$ acoustic Doppler current profilers (ADCPs), whereas all other moorings were equipped with $300-\mathrm{kHz}$ ADCPs to measure velocities in the upper $\sim 50 \mathrm{~m}$ (above the MMP range; see Fig. 3 ).
Expected accuracies for velocities and directions are $\pm 0.5 \mathrm{~cm} \mathrm{~s}^{-1}$ and $\pm 2^{\circ}$ with a vertical resolution of 2 and $5 \mathrm{~m}$ for the $300-$ and $75-\mathrm{kHz}$ ADCPs, respectively. Unfortunately, the common problem of acoustic surface reflection rendered the upper $\sim 10(300 \mathrm{kHz})$ and $25 \mathrm{~m}$ $(75 \mathrm{kHz})$ ADCP observations unusable. In addition, the $\mathrm{ADCP}$ at $\mathrm{M} 1_{5}$ stopped working after about one year. All data were linearly interpolated (MMP) or averaged (MicroCAT, ADCP) to daily values prior to analysis. The data are available online (at https://arcticdata.io/catalog/ \#view/arctic-data.7792.4 or http://research.iarc.uaf. edu/NABOS2/data/registered/main.php).

The Arctic Ocean Atlas, compiled by the U.S.-Russian Environmental Working Group (Timokhov and Tanis 1997), provides gridded hydrographic data from the Arctic Ocean over decadal periods spanning the 1950s to the 1980s. The horizontal resolution is $50 \mathrm{~km}$ and vertical resolution decreases from $5 \mathrm{~m}$ at the surface to $500 \mathrm{~m}$ below 1000-m depth. We use this data as a historic reference state for eastern EB hydrography $\left(77^{\circ}-85^{\circ} \mathrm{N}, 95^{\circ}-145^{\circ} \mathrm{E}\right)$.

Finally, daily ERA-Interim output with a spatial resolution of $0.75^{\circ}$ for both latitudes and longitudes 


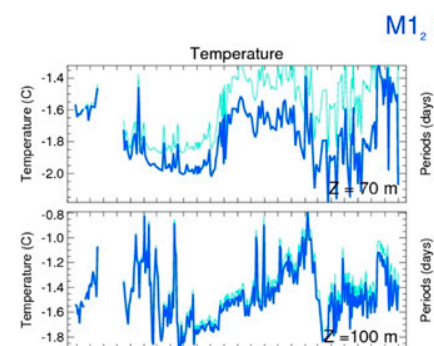

$\mathrm{M1}_{2}$ mooring
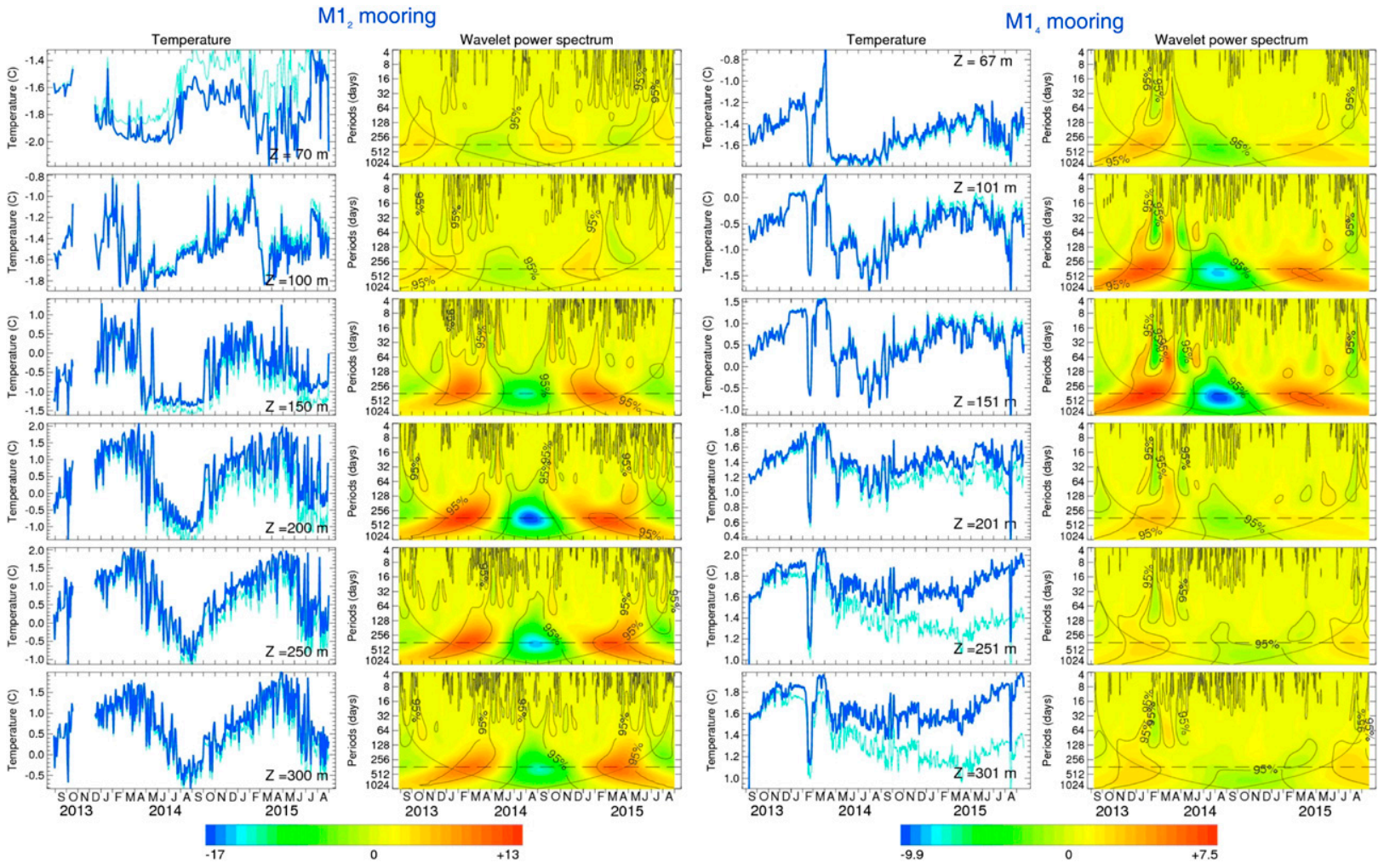

FIG. 4. (left) Original (light blue) and (right) detrended (dark blue) time series and wavelet transforms of the detrended time series of temperature at moorings $\mathrm{M}_{2}$ and $\mathrm{M}_{4}$. Solid black lines indicate the $95 \%$ confidence interval and the cone of influence. The horizontal dashed lines mark the seasonal (365 day) period of the wavelet transform.

(Dee et al. 2011) is utilized to evaluate the seasonal wind field over the eastern EB for the mooring deployment period (2013-15).

In this study, seasonality is evaluated using two different measures.

First, seasonal cycles are defined based on calendric seasons, where seasonal differences are calculated by subtracting wintertime [December-January-February (DJF)] averages from summertime [July-AugustSeptember (JAS)] averages (note that we chose JAS as summer months to include September, the month of minimum sea ice areal extent in our definition of Arctic summer). Second, wavelet analysis is employed to identify seasonal cycles. We used a standard package of wavelet programs by Torrence and Compo (1998) and calculated the wavelet transforms with the derivative of Gaussian (DOG) mother function. The package also provided estimates for the $95 \%$ confidence intervals and cones of influence, indicating where the edges of the domain affect the wavelet. Time series of seasonal wavelet amplitudes with physical units $\left({ }^{\circ} \mathrm{C}, \mathrm{cm} \mathrm{s}^{-1}\right.$, salinity) were obtained by regressing the wavelet transform at seasonal frequency (wavelet period closest to 365 days) onto the original (detrended) time series. With this measure, we define the halved differences between maxima and minima of the seasonal wavelet amplitude time series as seasonal amplitudes.

While seemingly redundant, both seasonal differences and wavelet-based seasonal amplitudes complement each other in that the former illustrates what is observed in a predefined seasonal frame (i.e., summer vs winter) while the latter provides total magnitudes of variability at seasonal time scales.

\section{Seasonal signal over the eastern EB continental slope}

Wavelet analysis of temperature ${ }^{1}$ time series reveals that the seasonal cycle is the dominant mode of variability in our two-year-long records. This is evident throughout the observed water column and at all mooring locations across the eastern EB continental slope. However, the position, vertical spread, and phase

\footnotetext{
${ }^{1}$ All mentions of "temperature" in this study are actually "potential temperature". Likewise all mentions of "density" refer to "potential density", referenced to the surface.
} 
of the strongest seasonal signals in the water column vary widely across the slope (shown for $\mathrm{M}_{2}$ and $\mathrm{M}_{4}$ in Fig. 4). This variety can be broken down into three patterns of seasonality in three separate domains, hereafter referred to as upper ocean (UO), upper-slope domain (USD; moorings $\mathrm{M}_{1}-\mathrm{M} 1_{3}$ ), and lower-slope domain (LSD; moorings $\mathrm{M}_{4}-\mathrm{M}_{6}$ ). In the following sections, we document the properties of the seasonal cycles in these three domains.

\section{a. Seasonal signal in temperature and salinity}

\section{1) SEAsonal CyCle in THE UPPER OCEAN}

The seasonal cycle in the upper $(<100 \mathrm{~m})$ part of the water column, comprising the SML and CHL, is described using the offshore-most mooring $\mathrm{M}_{6}$ since it provides the observations closest to the sea surface (up to 28-m depth) among all the moorings across the section (the other moorings only reach up to 55-77-m depth). Upperocean profiles from the gridded Arctic Ocean Atlas at all mooring locations suggest that the surface water becomes continuously fresher and warmer (in summer) toward the shelf. While this likely influences the SML depth, we argue that the general drivers for upper-ocean seasonality (sea ice cycle and atmospheric forcing) are comparable throughout the array, thus allowing us to use $\mathrm{M} 1_{6}$ as a proxy for upper-ocean seasonality across the slope.

Figure 5 shows the time series and their wavelets for temperature and salinity at different depths in the upper ocean at the $\mathrm{M}_{6}$ mooring position. The upper-ocean variability is characterized by strong seasonality of temperature and salinity with an underlying trend. At the uppermost available depth level $(28 \mathrm{~m})$, the variability of the detrended salinity ranges between 31.8 and 33.2 with seasonal minima in October-November and maxima in late April-May for both years. Seasonal differences reach $0.16^{\circ} \mathrm{C}$ and 0.17 for temperature and salinity, respectively. The wavelet-derived amplitudes of the seasonal signal are $0.12^{\circ} \mathrm{C}$ and 0.53 . The detrended seasonal temperature signal peaks at $\sim-1.6^{\circ} \mathrm{C}$ in midSeptember, with short-lived events increasing the summer temperature up to $-1.4^{\circ} \mathrm{C}$ in 2014 . Through winter, temperature decreases as salinity increases and reaches minima around $-1.8^{\circ} \mathrm{C}$ (freezing point) in March-April for both years. The phases between the seasonal cycles of temperature and salinity are thus shifted by about one month, with salinity trailing temperature.

At $50 \mathrm{~m}$, the amplitude of the seasonal signal is reduced by $\sim 50 \%$ for salinity, but much less so for temperature (Fig. 5, middle panels). Deeper, at $76 \mathrm{~m}$, the seasonal cycle of salinity is in phase with that of temperature, in contrast to their opposition in the upper ocean (Fig. 5, lower panels vs upper panels), indicating the influence of an independent seasonal signal within the halocline, which will be described in section $3 \mathrm{a}(3)$.

On the other hand, depth-time diagrams of temperature and salinity provide evidence for seasonal variability in the halocline (down to 140-m depth) resembling that of the surface seasonality (Figs. 6a,b). For example, ventilation of the upper ocean led to isotherm/isohaline deepening throughout the halocline.

The seasonal evolution of the SML depth at the M16 mooring location is shown in Figs. 6a and 6b (white lines). In calculating SML depth, we followed Monterey and Levitus (1997), who defined the SML thickness by the depth at which density exceeds the surface density by $0.125 \mathrm{~kg} \mathrm{~m}^{-3}$ (in our case, the surface density was approximated by the density of the uppermost available observation). Note that while the available mooring data restricted to below $28 \mathrm{~m}$ allow reliable definition of the SML depth in winter, the summer estimate of $30 \mathrm{~m}$ is very close to the shallow limit of observations and thus requires further justification. Summer CTD profiles carried out near $\mathrm{M1}_{6}$ indicated that SML depths were 22-m SML depth in 2013 and $23 \mathrm{~m}$ in 2015. These values are somewhat less than our estimate of $\sim 30 \mathrm{~m}$ derived from the mooring data, but we argue that they are close enough to justify the approach. The prominent feature of the observed seasonal signal is a deepening of the SML from $\sim 30 \mathrm{~m}$ in summer to $\sim 80 \mathrm{~m}$ in winter.

\section{2) SEASONAL CYCLE IN THE UPPER-SLOPE DOMAIN}

The USD spanning from the $\mathrm{M} 1_{1}$ mooring (250-m water depth) to the $\mathrm{M}_{3}$ mooring (1850-m water depth) is rather narrow (covering $65 \mathrm{~km}$ of the upper slope), and all mooring records are influenced by the proximity to the hydrographic front. Because the front is apparent in between moorings $\mathrm{M}_{2}$ and $\mathrm{M}_{3}$ (cf. sloping isopycnals in Figs. 7a-d), its exact location cannot be determined. However, ship-based CTD sections of up to 19 casts across the slope undertaken in summers 2013 and 2015 suggest that the front lies just offshore of the $\mathrm{M}_{2}$ mooring position (750-m depth; not shown), at least in late summer. Seasonal differences in the USD show a strong temperature signal spreading throughout the observed water column below $\sim 100 \mathrm{~m}$. Specifically, at the $\mathrm{M} 1_{1}$ and $\mathrm{M} 1_{2}$ mooring locations, the seasonal cycle features colder summers compared to winters below $100 \mathrm{~m}$ as shown in cross-slope sections (Figs. 7a,c) and temperature-salinity $(\theta-S)$ diagrams (Fig. 8, upper panels). Seasonal temperature differences (summers minus winters) peak at $-1.4^{\circ} \mathrm{C}$ at 180-m depth (Fig. 7e). Wavelet-based amplitudes of the seasonal signal reach $0.8^{\circ}-0.9^{\circ} \mathrm{C}$ between 160 - and $300-\mathrm{m}$ depth at $\mathrm{M}_{2}$ and decrease gradually to $\sim 0.4^{\circ} \mathrm{C}$ at $600-\mathrm{m}$ depth (Fig. 9, top). 


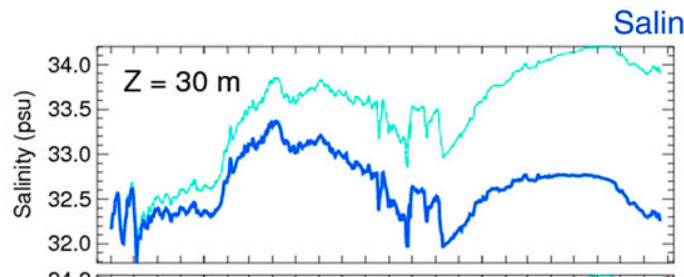

Salinity, $\mathrm{M} 1{ }_{6}$ mooring
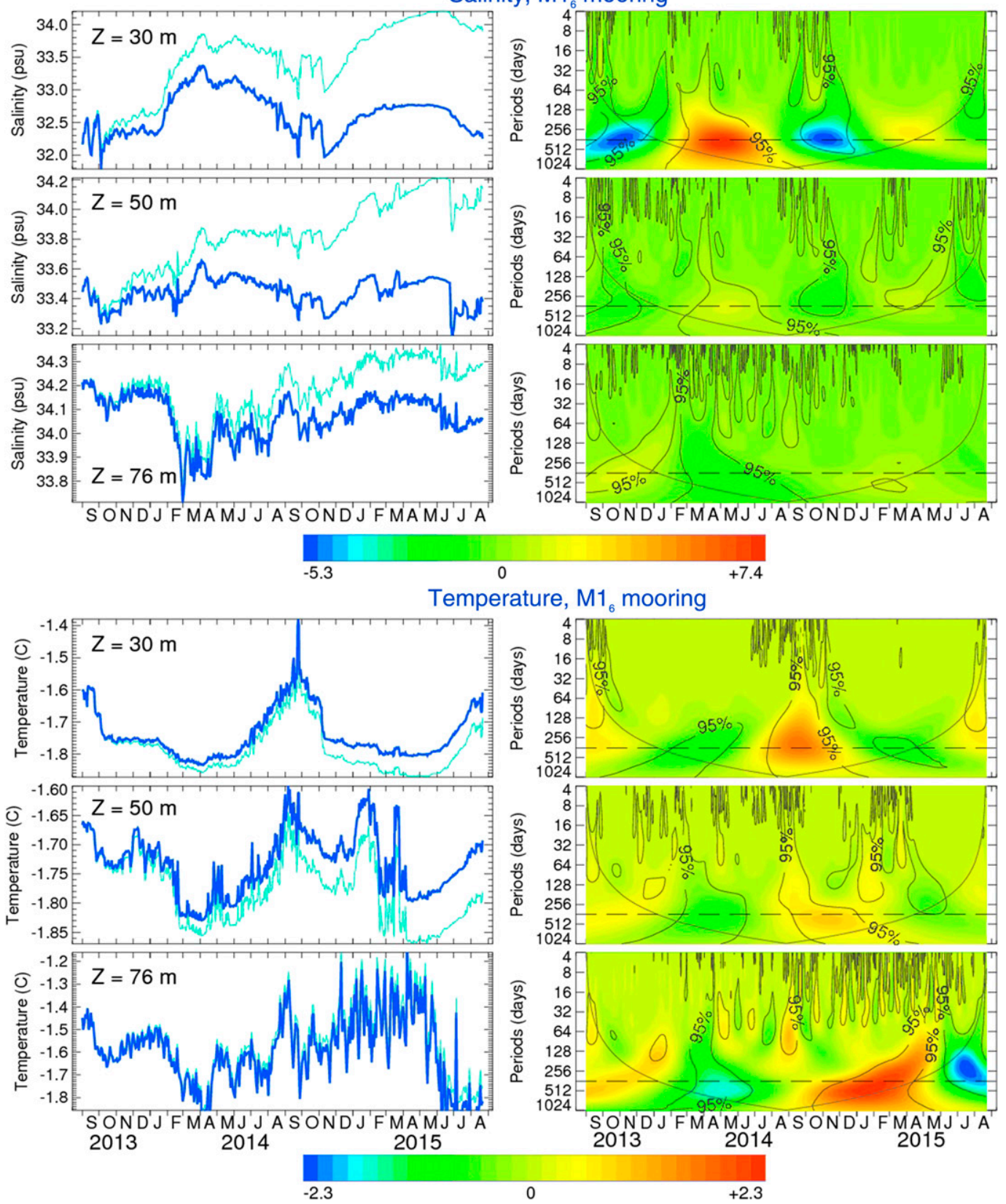

FIG. 5. (left) Original (light blue) and detrended (dark blue) time series and (right) wavelet transforms of detrended time series of (top) upper-ocean salinity and (bottom) temperature at the $\mathrm{M} 16$ mooring. Solid black lines indicate the $95 \%$ confidence interval and the cone of influence. The horizontal dashed lines mark the seasonal (365 day) period of the wavelet transform.

Contrasting with the more-onshore moorings $\mathrm{M} 1_{1}$ and $\mathrm{M} 1_{2}$, the $\mathrm{AW}$ at $\mathrm{M} 1_{3}$ shows higher summer temperatures compared to winters with seasonal differences and wavelet-derived amplitudes both reaching $0.5^{\circ} \mathrm{C}$, which is smaller than the seasonal change observed at $\mathrm{M}_{2}$ (Fig. 7e and Fig. 9, top). A common feature shared by all USD moorings $\left(\mathrm{M}_{1}-\mathrm{M} 1_{3}\right)$ is the vast vertical spread of temperature seasonality throughout the water column in the vicinity of the hydrographic front.

The seasonality of salinity exhibits a very different pattern compared to temperature. Below $\sim 100 \mathrm{~m}$, in the region of the strongest temperature signal, seasonality of salinity is small, with summertime fresher water $(\sim 150-250 \mathrm{~m})$ above summertime saltier water 

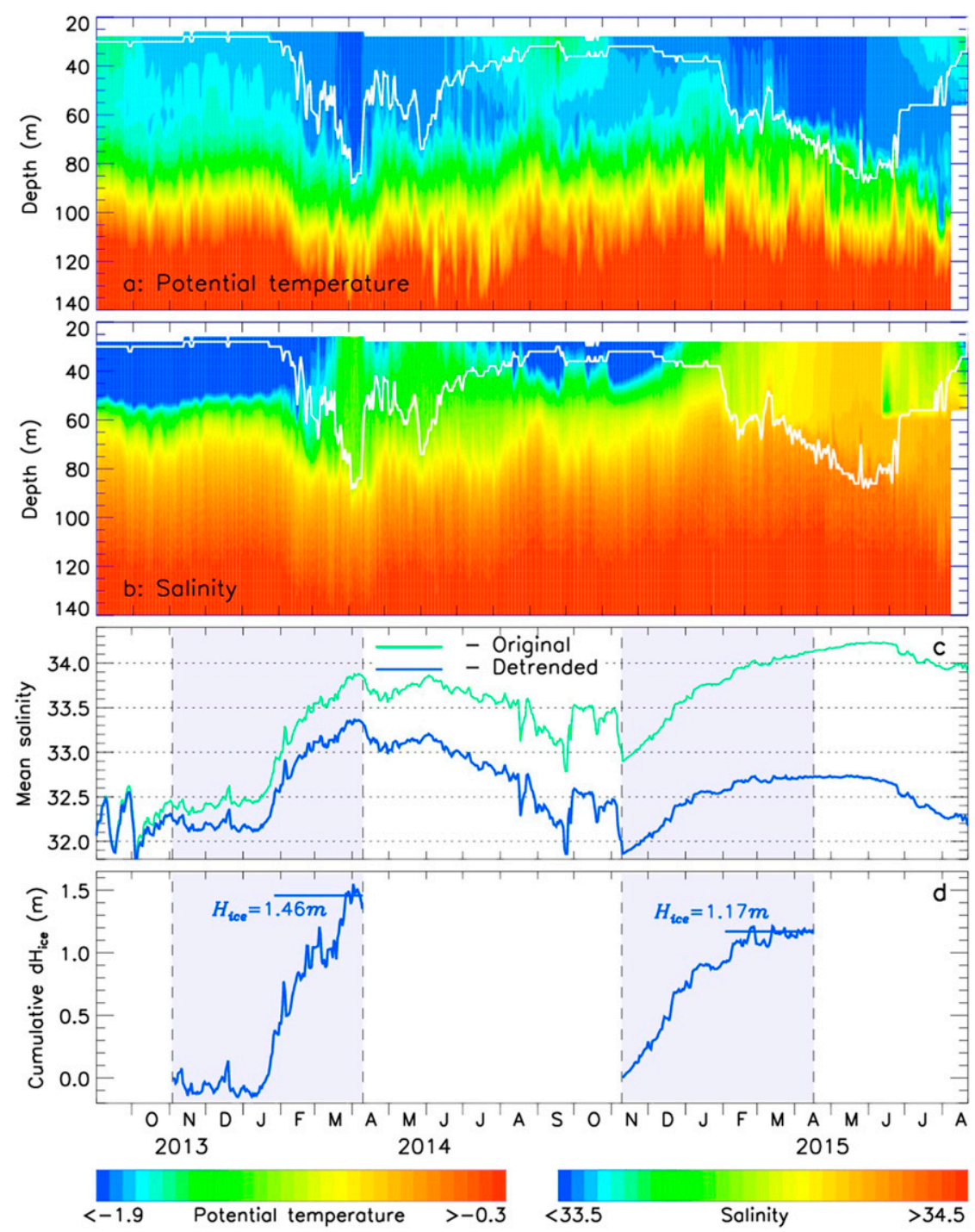

FIG. 6. (a),(b) Time series of upper water column temperature and salinity at $\mathrm{M} 16$, respectively. The white line indicates the SML boundary. (c) Salinity averaged over the SML. (d) Ice growth calculated from the salinity increase during winter, representing brine rejection. Shading in (c) and (d) marks the ice-growing season based on salinity increases.

( $>400 \mathrm{~m}$ ) (Fig. 7f). The amplitude of the salinity signal is generally lower than 0.06 (Fig. 9, middle). An exception is the strong salinity seasonality in the CHL (shallower than $\sim 100$-m depth) at $\mathrm{M}_{2}$ and $\mathrm{M} 1_{3}$ mooring locations that reaches a maximum seasonal difference of 0.2 at the very top of the observed water column $(70 \mathrm{~m})$ at both moorings and rapidly decreases with increasing depth (Fig. 7f). The $\theta-S$ diagrams reveal that the seasonal thermohaline properties of this signal are essentially collinear along the salinity axis, especially at $\mathrm{M}_{2}$ (Fig. 8, diamonds). This suggests that isopycnal displacement, rather than a seasonal change of water mass may be the source of this signal. The absence of this signal in isopycnal coordinate plots further supports this notion (Figs. 7e,g,h). Unfortunately, because only the deepest part of the signal $(>\sim 70 \mathrm{~m})$ is captured, a meaningful quantification of the isopycnal displacement is not feasible. However, in the following section, we will demonstrate that this signal is similar to the seasonality observed in the LSD (albeit centered in the LHW at $>100-\mathrm{m}$ depth and not in the CHL).

\section{3) SEASONAl CYCLE IN THE LOWER-SLOPE DOMAIN}

In the LSD (moorings $\mathrm{M}_{4}-\mathrm{M} 1_{6}$ ), beneath the upperocean domain, the seasonal cycle is confined to the halocline and upper AW layer ( $\sim 100-200 \mathrm{~m})$ with colder and fresher summers relative to winters (Figs. 7e,f and 8). Maximum seasonal salinity and temperature differences are -0.11 

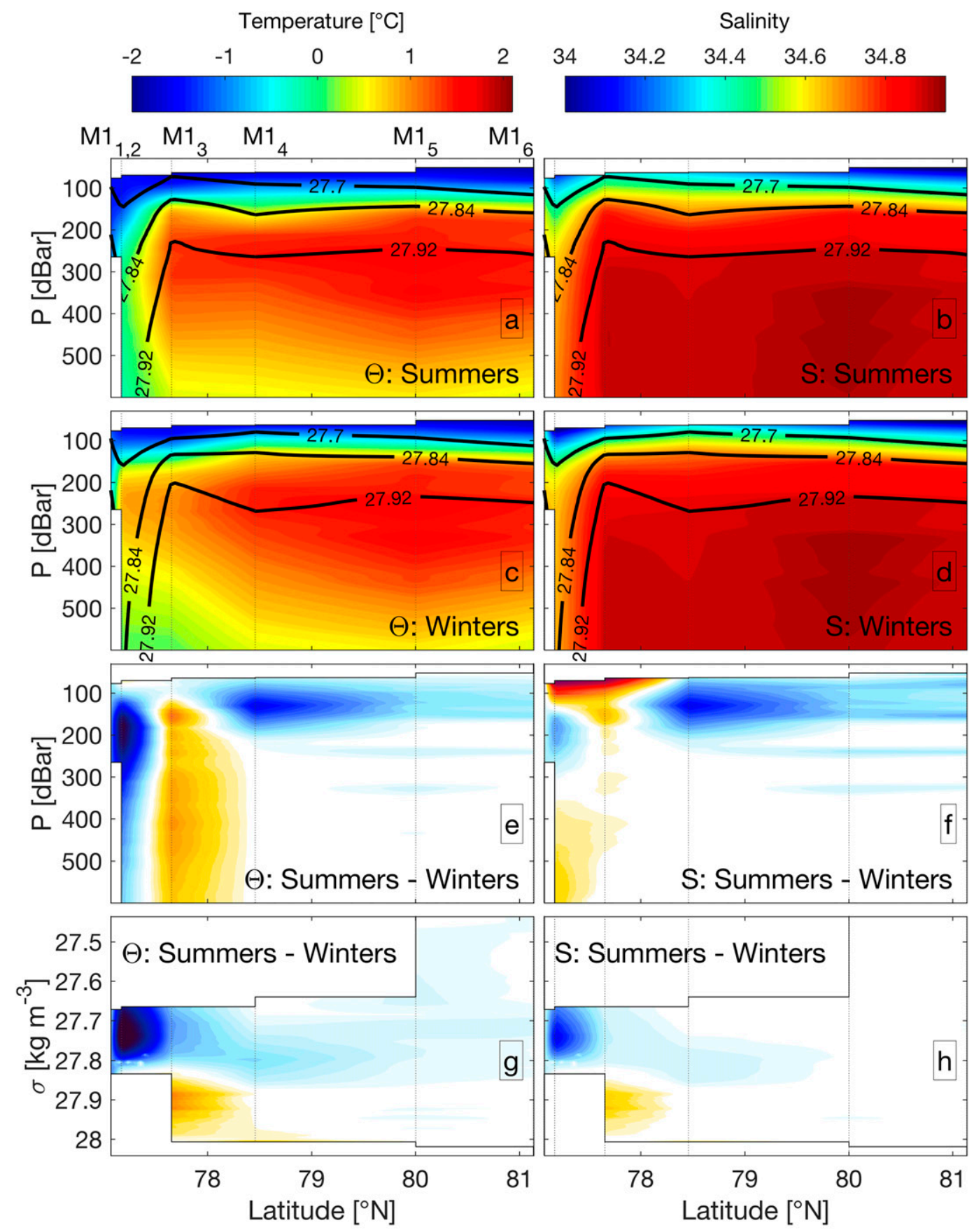

Temperature $\left[{ }^{\circ} \mathrm{C}\right]$
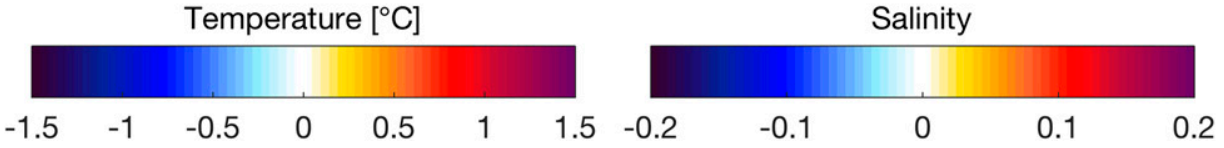

FIG. 7. (a)-(d) Sections of moored observations of seasonal temperature $\theta$ and salinity $S$. Black contours are the 27.7, 27.84, and 27.92 isopycnals. Dashed lines and figure borders indicate mooring positions [as indicated above in (a)]. (e),(f) Seasonal differences of $\theta$ and $S$. (g),(h) As in (e) and (f), but with density as the vertical coordinate. 

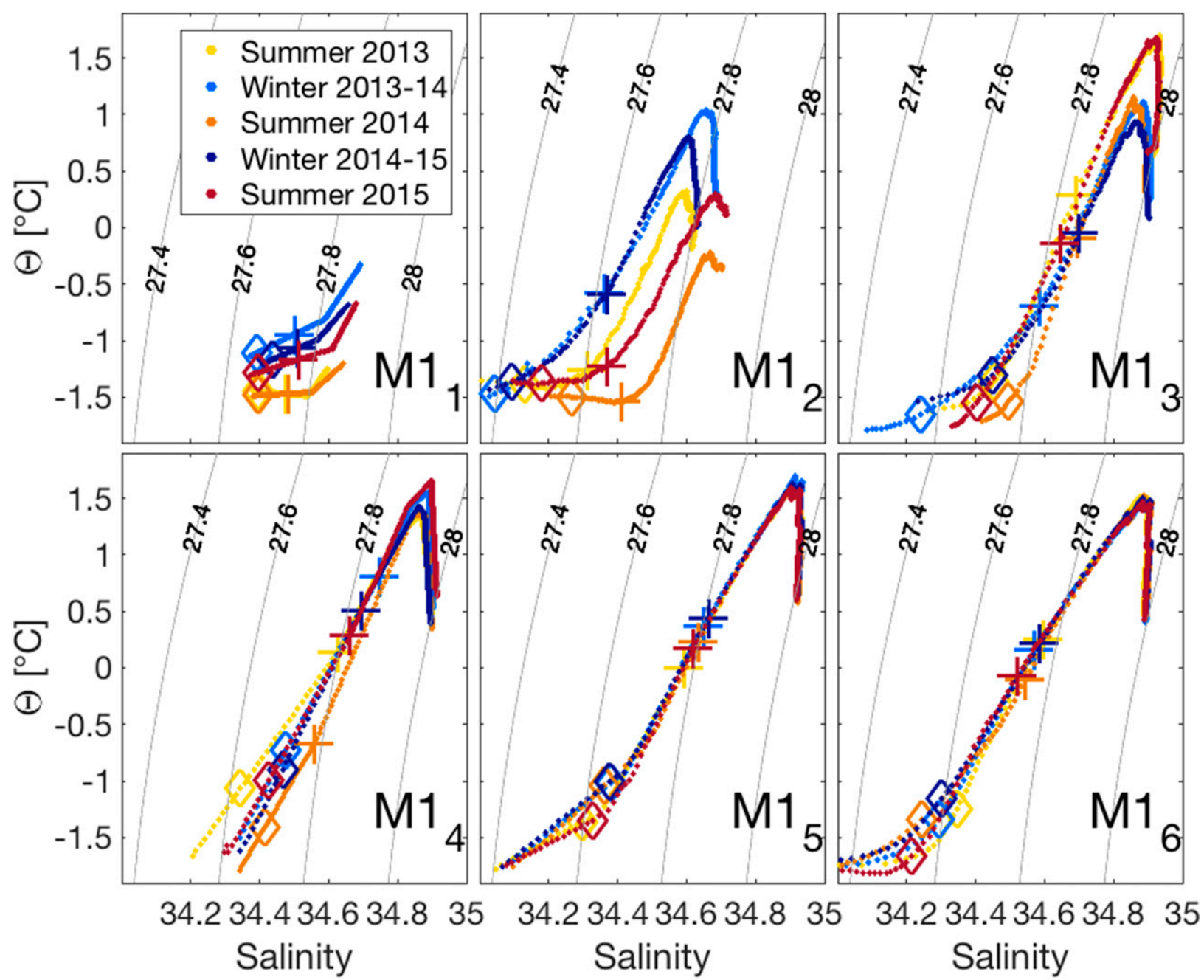

FIG. 8. The $\theta-S$ diagrams for the cross-slope mooring array in the eastern EB. Contours show isopycnals. Color notation for the seasonal averaging is shown in the insert. Diamonds and crosses denote thermohaline properties at 85- and 130-m depth, respectively.

and $-0.83^{\circ} \mathrm{C}$, while wavelet-derived amplitudes reach maxima of 0.1 and $0.77^{\circ} \mathrm{C}$ for salinity and temperature, respectively, at $\sim 130$-m depth at the $\mathrm{M} 1_{4}$ mooring location (Fig. 9, top and middle). Colder and fresher summers compared to winters are also evident in historical records from the 1950s through the 1980s (Fig. 2). However, while in this early period the temperature signal was found between 100- and 300-m depth with the maximum located around $200 \mathrm{~m}$, in recent years, the maximum seasonal cycle in the LSD was considerably shallower, centered around 130-m depth.

The seasonal thermohaline properties around $130 \mathrm{~m}$ (marked by crosses in Fig. 8, lower panel) are practically collinear, thus indicating little seasonal water mass change in the halocline and upper AW. Similar to the CHL salinity signal found in the USD, the spread of the crosses suggests that the observed seasonal signal is due to a vertical displacement of isopycnals. Analysis of the LSD seasonal changes on isopycnal surfaces supports this finding: Figs. $7 \mathrm{~g}$ and $7 \mathrm{~h}$ show that the temperature and salinity differences presented in a density coordinate system exhibit almost no seasonal signal in the halocline (around the $\sigma=27.84 \mathrm{~kg} \mathrm{~m}^{-3}$ level). Comparison of seasonal density profiles showed a 36-m isopycnal displacement between summers (low) and winters (high) at $\sim 130$-m depth at $\mathrm{M}_{4}$ (Fig. 10). Note that this measure of isopycnal displacement depends on linear vertical interpolation between the available discrete measurements and should thus be regarded as point of reference only.

\section{b. Seasonal signal in current velocities}

Velocity measurements reach up to 10-25-m depth at most moorings. Thus, these time series of current speed records and their wavelet analysis provide an opportunity 

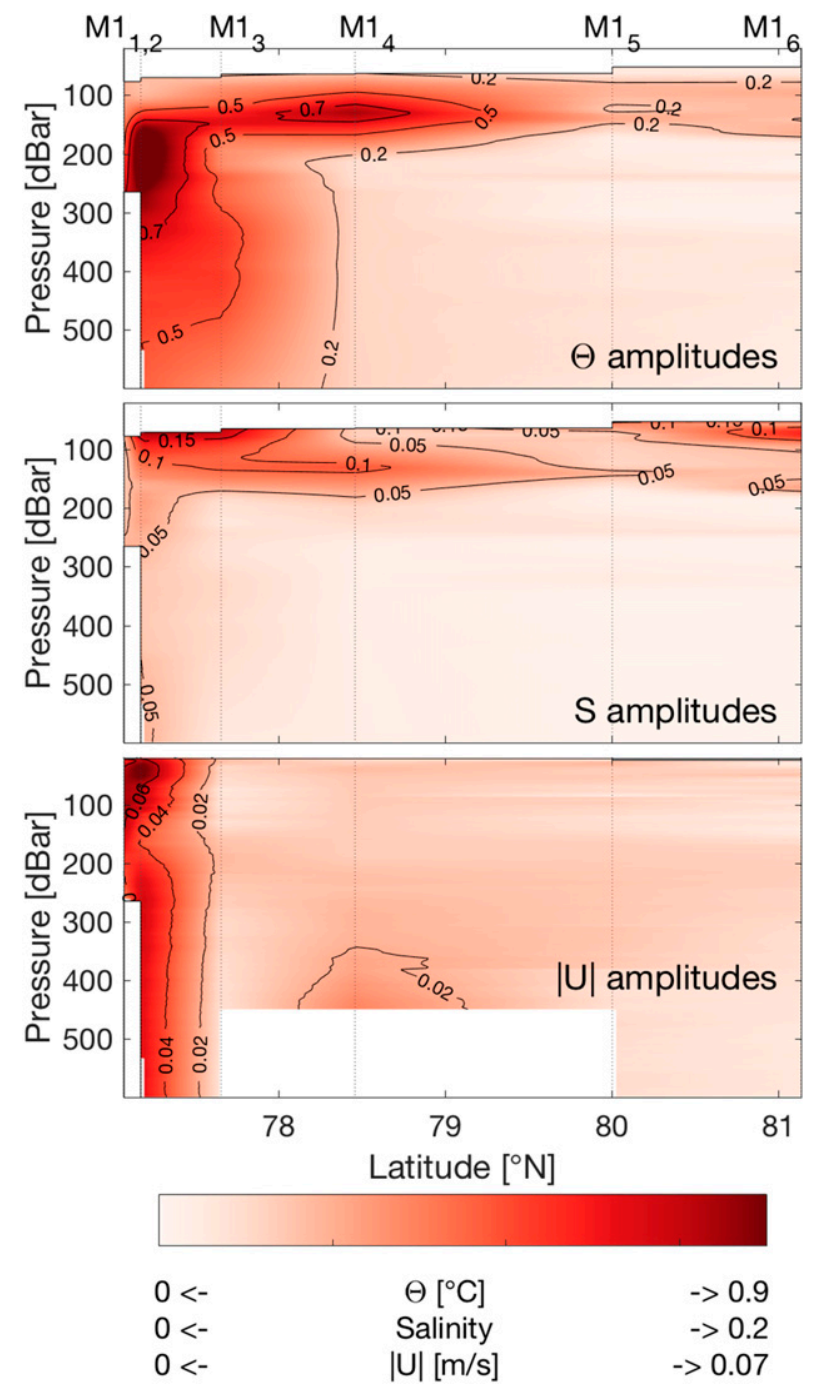

FIG. 9. Sections of wavelet derived seasonal amplitudes for temperature, salinity, and current speed.

to resolve details of the seasonal signal of oceanic currents within the SML (Fig. 11).

Within the SML, both moorings $\mathrm{M} 1_{2}$ and $\mathrm{M}_{4}$ feature seasonality with maximum current speed in SeptemberOctober and minima in April. This agrees with the storm activity pattern for the Laptev Sea area derived from land-based stations that show highest storm frequency and intensity in October (Atkinson 2005). The waveletderived amplitudes of seasonal current speed within the SML differ greatly between the mooring locations, with $5.5 \mathrm{~cm} \mathrm{~s}^{-1}$ at $\mathrm{M} 1_{2}$ and $1.3 \mathrm{~cm} \mathrm{~s}^{-1}$ at $\mathrm{M}_{4}$ (Fig. 11 and Fig. 9, bottom). Figure 12a shows seasonally averaged SML currents. It becomes apparent that there is no consistent pattern linking current strength and season across the mooring array. While at $\mathrm{M}_{3}$ and $\mathrm{M} 1_{6}$ summer velocities are slightly greater, at $\mathrm{M}_{2}$ and $\mathrm{M}_{4}$

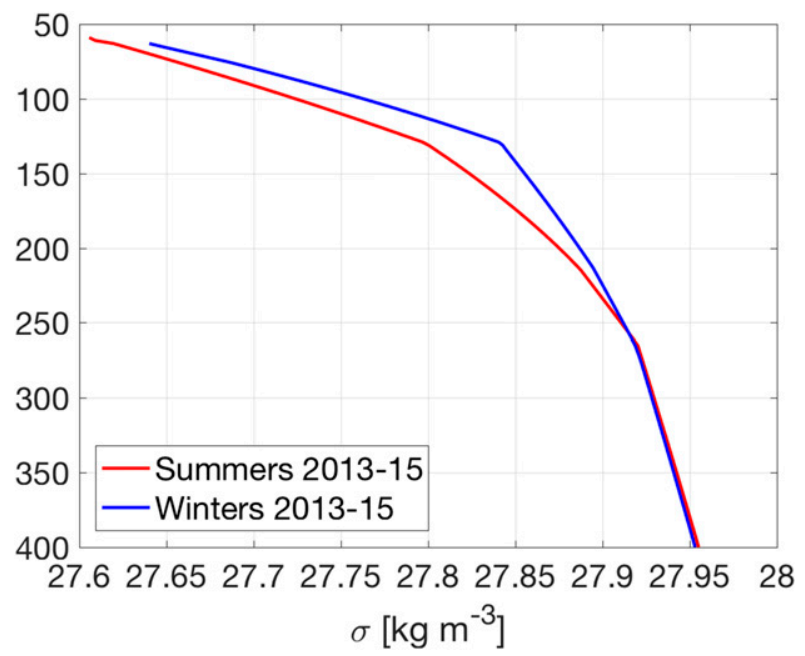

FIG. 10. Seasonal density profiles from individual instruments at the $\mathrm{M}_{4}$ mooring site.

the opposite is true. The flow on the steeper part of the slope, at moorings $\mathrm{M}_{2}-\mathrm{M}_{4}$, is mostly aligned with the underlying topography throughout all averaging periods, regardless of wind direction (cf. Fig. 13).

In the USD (in the vicinity of the hydrographic front), below the SML, the seasonal signal at the $\mathrm{M}_{2}$ mooring remains strong and evident from both visual inspection of the time series and wavelet analysis, with a notable delay of around three months between the surface and $300 \mathrm{~m}$ (Fig. 11). Wavelet-based amplitudes reach up to $7 \mathrm{~cm} \mathrm{~s}^{-1}$ in the upper $100 \mathrm{~m}$ at $\mathrm{M} 1_{1}$ and $\mathrm{M} 1_{2}$, decreasing farther offshore to $\sim 1 \mathrm{~cm} \mathrm{~s}^{-1}$ from $\mathrm{M}_{3}$ on (Fig. 9, bottom). In general, the mean currents at the $\mathrm{M} 1_{1}-\mathrm{M} 1_{3}$ mooring locations as well as the seasonally averaged currents are aligned with the topography (Fig. 12b).

In the LSD, offshore of the hydrographic front and below the SML $(\sim 25 \mathrm{~m})$, variability of the time series of current speed at the $\mathrm{M}_{4}$ mooring location is dominated by subseasonal fluctuations on time scales from days to months that mask the seasonal cycle. For example, the pronounced signal that passed the mooring in early 2015 produced a maximum in the wavelet analysis that extends to seasonal time scales, thus modulating the seasonal signal (Fig. 11). Wavelet-derived seasonal amplitudes are relatively small $\left(<2 \mathrm{~cm} \mathrm{~s}^{-1}\right)$ but consistent in magnitude throughout the LSD (Fig. 9). The only exception is a region of higher amplitude $\left(>2 \mathrm{~cm} \mathrm{~s}^{-1}\right)$ below $300 \mathrm{~m}$ at the $\mathrm{M}_{4}$ mooring location. Seasonally averaged currents in Fig. $12 \mathrm{~b}$ are also small $\left(<1 \mathrm{~cm} \mathrm{~s}^{-1}\right)$ with no discernible structure in their rotation. This indicates little seasonal persistence of current directions, possibly due to mesoscale fluctuations such as eddies. 


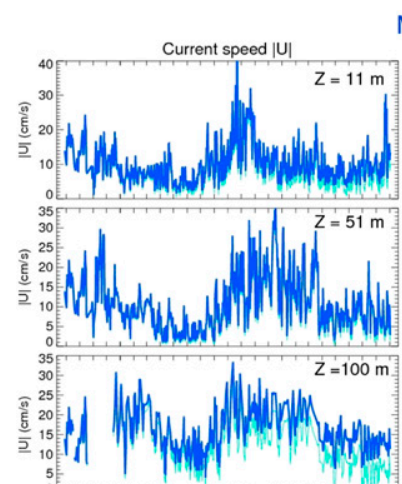

M1 ${ }_{2}$ mooring
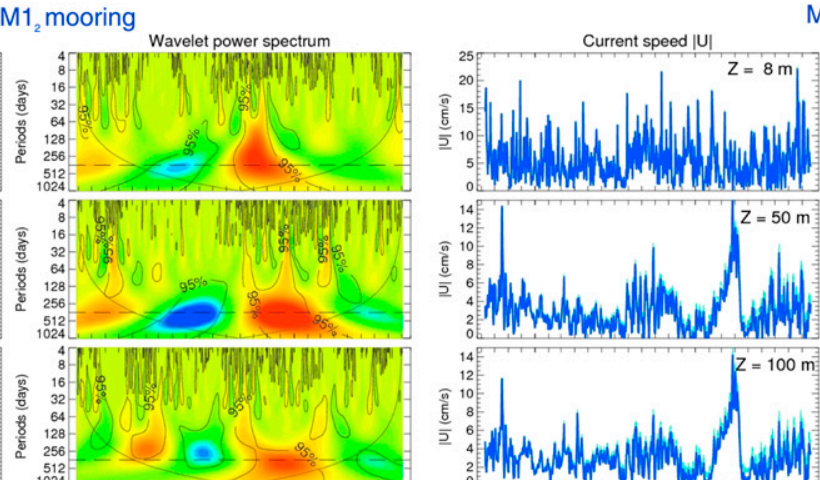

$\mathrm{M} 1{ }_{4}$ mooring
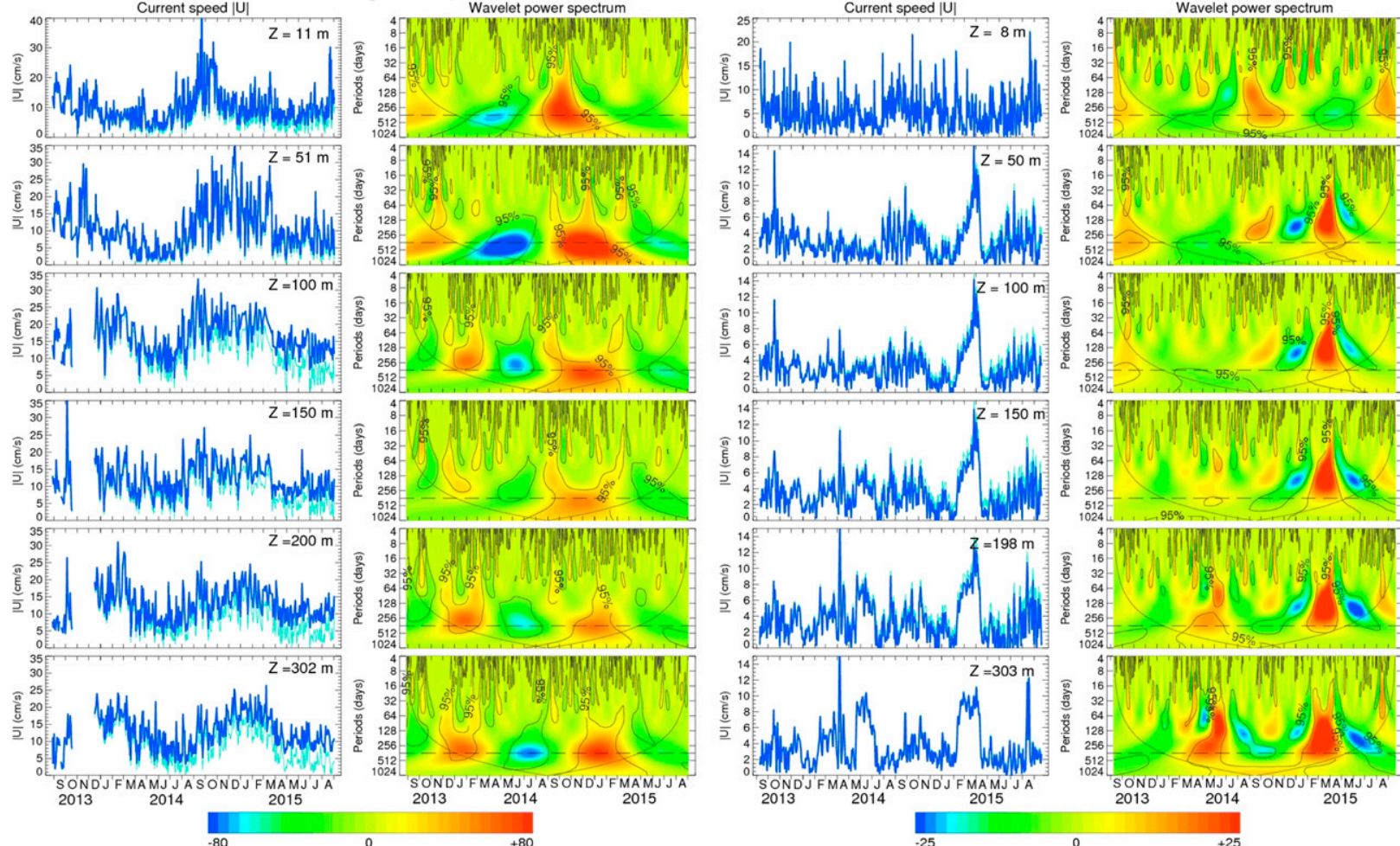

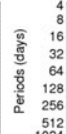
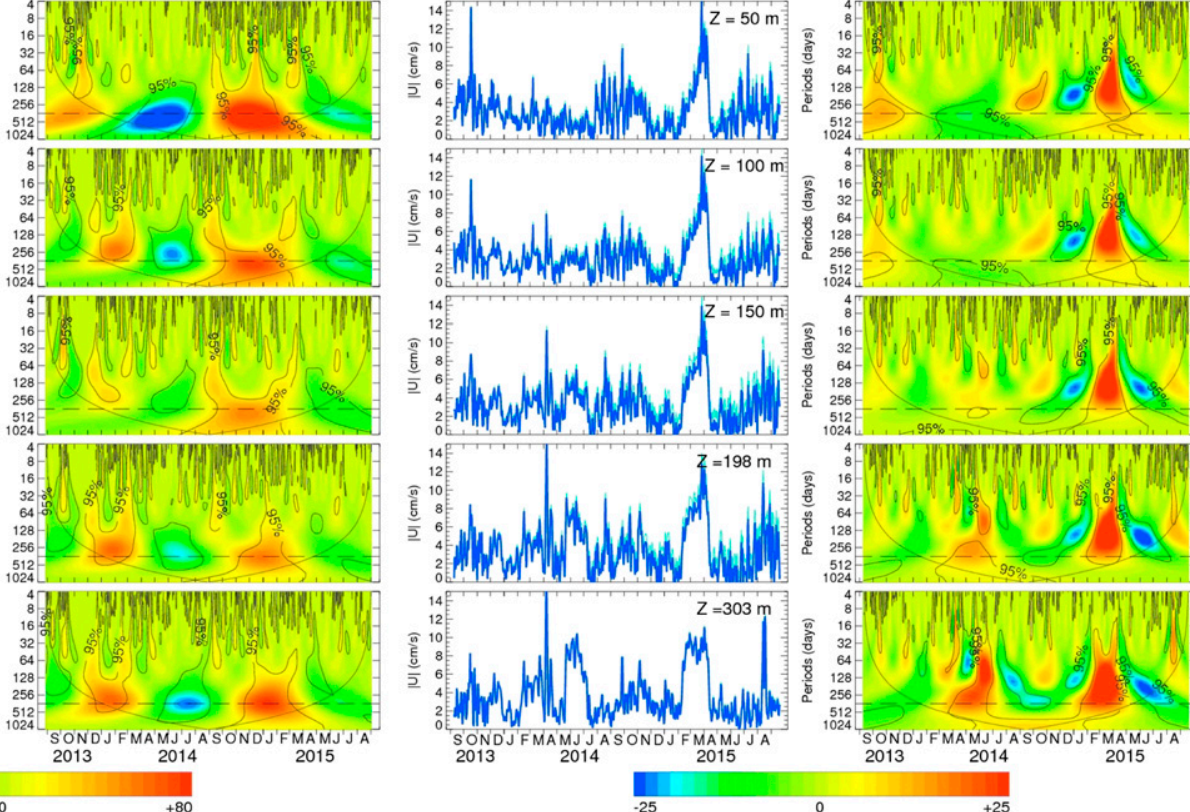

FIG. 11. (left) Original (light blue) and detrended (dark blue) time series and (right) wavelet transforms of detrended time series of current speed at moorings $\mathrm{M}_{2}$ and $\mathrm{M}_{4}$. Solid black lines indicate the $95 \%$ confidence interval and the cone of influence. The horizontal dashed lines mark the seasonal (365 day) period of the wavelet transform.

\section{Discussion of drivers for the observed seasonal cycles}

\section{a. Upper ocean}

\section{LOCAL ICE MELT AND FREEZING PROCESSES}

Processes associated with the annual sea ice cycle are the main driving factors behind the seasonal thermohaline cycle in the upper Arctic Ocean (e.g., Rudels et al. 1996). The fact that seasonal amplitudes for temperature and salinity at $30 \mathrm{~m}$ are substantially greater than at $50 \mathrm{~m}$ (as evidenced by wavelet analysis) supports the notion of seasonal forcing that originates at the surface (Fig. 5). Vertical mixing across the halocline is an important contributor to the observed SML seasonality (e.g., Fer et al. 2017; Polyakov et al. 2017). As shown in section $3 \mathrm{a}(1)$, there is an approximately onemonth delay of the seasonal salinity signal relative to that of temperature. After the SML temperature reaches its maximum in mid-September, its stored heat must be removed by surface cooling before freeze-up and related brine rejection can start, hence the offset. In winter, the SML temperature remains close to the freezing point, a function of salinity; therefore the winter maximum of salinity and minimum of temperature are in phase.

The seasonal increase of SML salinity in winter together with temperature decrease and deepening of the SML can be attributed to free convection driven by brine rejection during freeze-up (Figs. 6b,c). From the salinity change in the SML, a quantitative estimate of local ice formation can be derived assuming an average sea ice salinity of 3 , balanced with the observed average SML salinity. While the assumed salinity is on the lower side of the typical range for first-year Arctic sea ice salinity of 2-6 (Barry et al. 1993), changing the values of prescribed sea ice salinity has only minor effect on ice thickness $(\sim 3 \%$ thickness change per unit sea ice salinity). The estimates yield a sea ice thickness of $\sim 1.5 \mathrm{~m}$ in the first and $\sim 1.2 \mathrm{~m}$ in the second winter (Fig. 6d). Ice thickness measurements carried out by an upwardlooking sonar at the $\mathrm{M}_{4}$ mooring location yield a maximum monthly modal sea ice thickness of 1.44 and $1.42 \mathrm{~m}$ for 2014 and 2015, respectively, which is reasonably close to our estimates. Using satellite data acquired since 1982, Maslanik et al. (2007) showed that the eastern EB is covered almost exclusively with first year ice in winter. Note that because the shallowest observed depth 
a. $10-25 m$
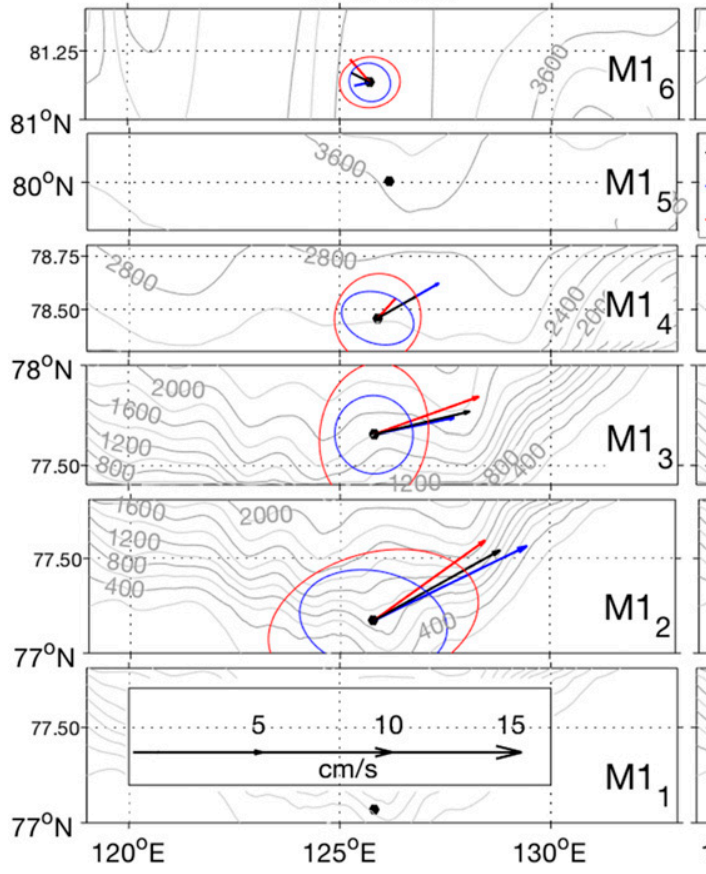

FIG. 12. (a) Current vectors across the mooring array averaged over the observed SML (10-25 m) and over seasons as well as associated ellipses of standard deviation; (bottom left) all vectors and ellipses are scaled as indicated. To improve readability, each mooring is in an individual panel (note that latitudes between panels may overlap). Owing to too-short records or missing data, no vectors are plotted at $\mathrm{M} 1_{1}$ and $\mathrm{M} 1_{5}$ (see data description in section 2). (b) As in (a), but for the ocean below the SML (25-300 m). Gray lines indicate topography.

level of $28 \mathrm{~m}$ is about $5-6 \mathrm{~m}$ deeper than late summer SML depth [as derived from CTD casts; see section 3a (1)], fall SML salinification associated to early season freeze-up cannot be observed until after the SML has deepened by $5-6 \mathrm{~m}$. However, the good agreement between the salinity-derived ice thickness and direct sonar measurements suggests a rapidly increasing SML depth at the onset of winter.

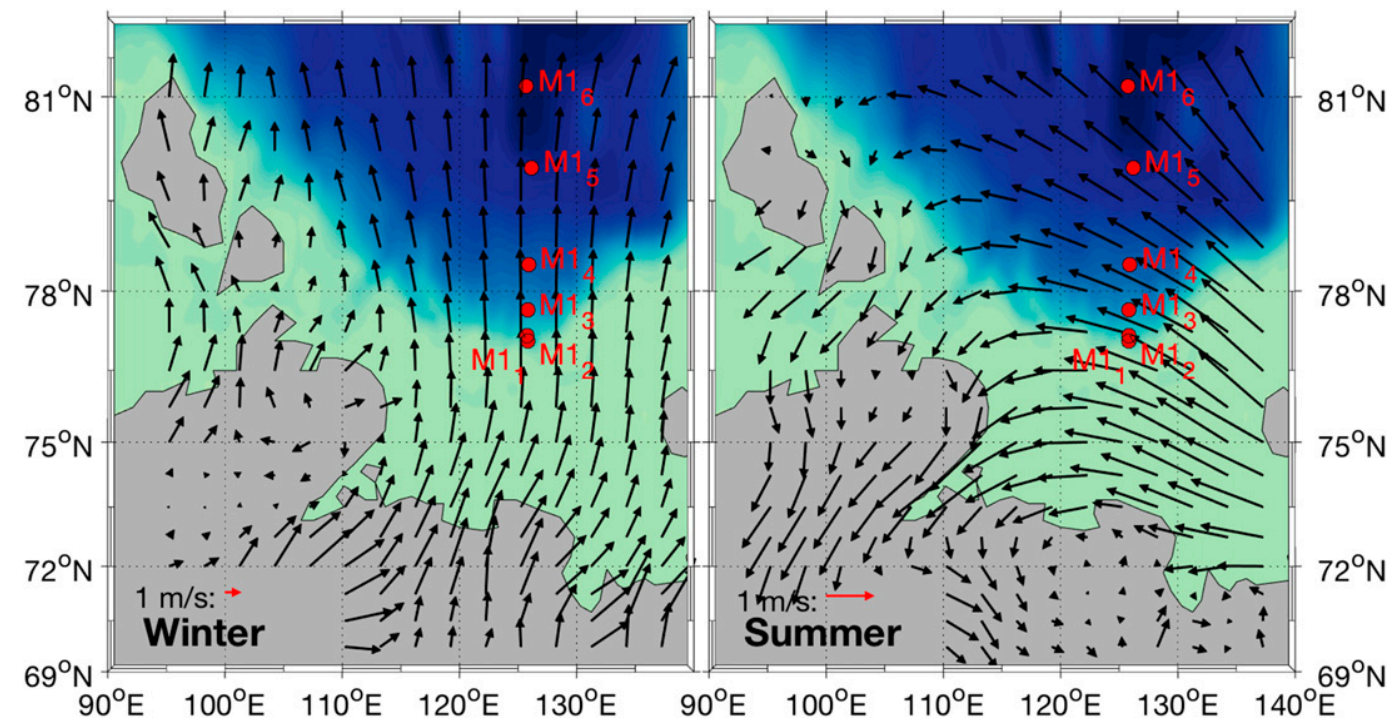

FIG. 13. ERA-Interim wind, averaged over (left) winters and (right) summers for the mooring deployment period 2013-15. Note the different scaling (red arrows) between the plots. 
Chemical analysis of the stable oxygen isotope ratio $\left(\delta^{18} \mathrm{O}\right)$ in water samples collected during the NABOS cruises in late summers 2013 and 2015 shows that up to $\sim 6 \%-10 \%$ of the water at $20-\mathrm{m}$ depth across the mooring section (above the reach of the moorings) consists of meteoric water (a characterization that includes both river water and precipitation) (not shown; see Alkire et al. 2017). The fact that meteoric water is present in the SML throughout the entire section indicates that sea ice may not be the sole factor modifying seasonally SML salinity.

\section{b. Upper-slope domain}

In this section, we identify possible drivers for the deep-reaching temperature signal in the vicinity of the front.

\section{1) Along-Stream AdVection}

In agreement with the description of signal advection within the ACBC (Pnyushkov et al. 2015), drivers for the observed seasonal cycle may originate from upstream locations. For example, Ivanov et al. (2009) found that seasonally changing surface waters off Spitsbergen retain their seasonality as they propagate to intermediate depths during their advection along the continental slope. A caveat of this hypothesis is that velocities change substantially across the slope (Fig. 12b), making it questionable as to whether the original upstream signal would "survive" a long period of advection all the way from Spitsbergen to the study site (approximately $1900 \mathrm{~km}$ ) without being completely distorted by different advection rates across the slope.

On smaller spatiotemporal scales, this may look different, however. The seasonal signal in temperature with opposing sign at $\mathrm{M}_{2}$ and $\mathrm{M} 1_{3}$ may be interpreted as originating from a common upstream signal whose phase is shifted between the two moorings owing to sheared flow during advection from the source to the mooring section. From the phase shift $(\sim 2.5$ months; not shown) and the average current speed difference between the moorings $\left(4.3 \mathrm{~cm} \mathrm{~s}^{-1}\right)$, it emerges that under the assumption of a constant along-stream advection rate, the source signal would have to originate $\sim 270 \mathrm{~km}$ upstream of the mooring array. This point of origin coincides with the Vilkitsky Strait (VS) outflow (see Fig. 1). Numerical models and chemical analyses suggest that seasonally varying volumes of cold and relatively fresh Kara Sea shelf water flow through the Vilkitsky Strait and Trough and merge with the ACBC to propagate eastward along the upper part of the continental slope (Aksenov et al. 2011; Bauch et al. 2016; Janout et al. 2015). While Aksenov et al. (2011) suggested that the waters entering the Laptev Sea through the Vilkitsky
Strait overlay waters within the ACBC, Janout et al. (2015) argued that the interaction between the two merging water flows is not well known and requires further investigation. With no data available to quantify the process, we can only point toward the possibility that Vilkitsky Strait outflows either mix with ACBC waters or push them farther offshore. The latter may be similar to processes farther upstream, where the Barents Sea branch of the AW acts to displace the Fram Strait branch from the upper slope farther offshore into the basin interior as they converge at the St. Anna Trough (e.g., Rudels et al. 2000).

\section{2) WIND-DRIVEN UPWELLING AT THE SLOPE}

Dmitrenko et al. (2006) analyzed AW seasonality using mooring data from 2002-04 at the eastern EB continental slope and identified seasonally changing wind patterns as the main driver behind the observed AW seasonal cycle, which they interpreted as crossshore shift of the AW core. The wind pattern in recent years has changed: for the 2013-15 deployment period, ERA-Interim data shows that summer wind conditions were generally easterly (Fig. 13), as opposed to westerly during 2003 [the only year for which Dmitrenko et al. (2006) had summer data], therefore favoring upwelling as opposed to downwelling. Likewise, easterly wind conditions prevailed when Janout et al. (2013) observed upwelling signatures in current profiles and thermohaline properties farther onshore on the Laptev Sea shelf in 2009 and 2010.

During the deployment period, upwelling-favorable wind conditions (northeasterly to southeasterly) occurred about twice as often during summer ( $44 \%$ of days) compared to winter ( $23 \%$ of days). For comparison, the opposite downwelling-favorable wind conditions (northwesterly to southwesterly) occurred only on $15 \%$ and $12 \%$ of days in summer and winter, respectively. The direct effect of wind stress on the ocean is confined to the Ekman layer, in which a balance of turbulent drag and Coriolis force is established (described by Ekman 1905). The depth of this layer is given by

$$
d_{E}=\sqrt{2 K_{m} / f},
$$

with the Coriolis parameter $f$ and the turbulent diffusivity $K_{m}$. For a typical value of $K_{m}=0.1 \mathrm{~m}^{2} \mathrm{~s}^{-1}$ and $f=$ $1.417 \times 10^{-4} \mathrm{~s}^{-1}$ at $77^{\circ} \mathrm{N}$, the estimated depth of the Ekman layer is $37 \mathrm{~m}$. The effect of up- and downwellingfavorable winds on cross-shore currents relative to the velocity at the bottom of the Ekman layer can be seen in Fig. 14a. There is a surface intensified offshore current anomaly reaching $2.8 \mathrm{~cm} \mathrm{~s}^{-1}$ at $9-\mathrm{m}$ depth during upwelling-favorable winds and a moderate onshore 


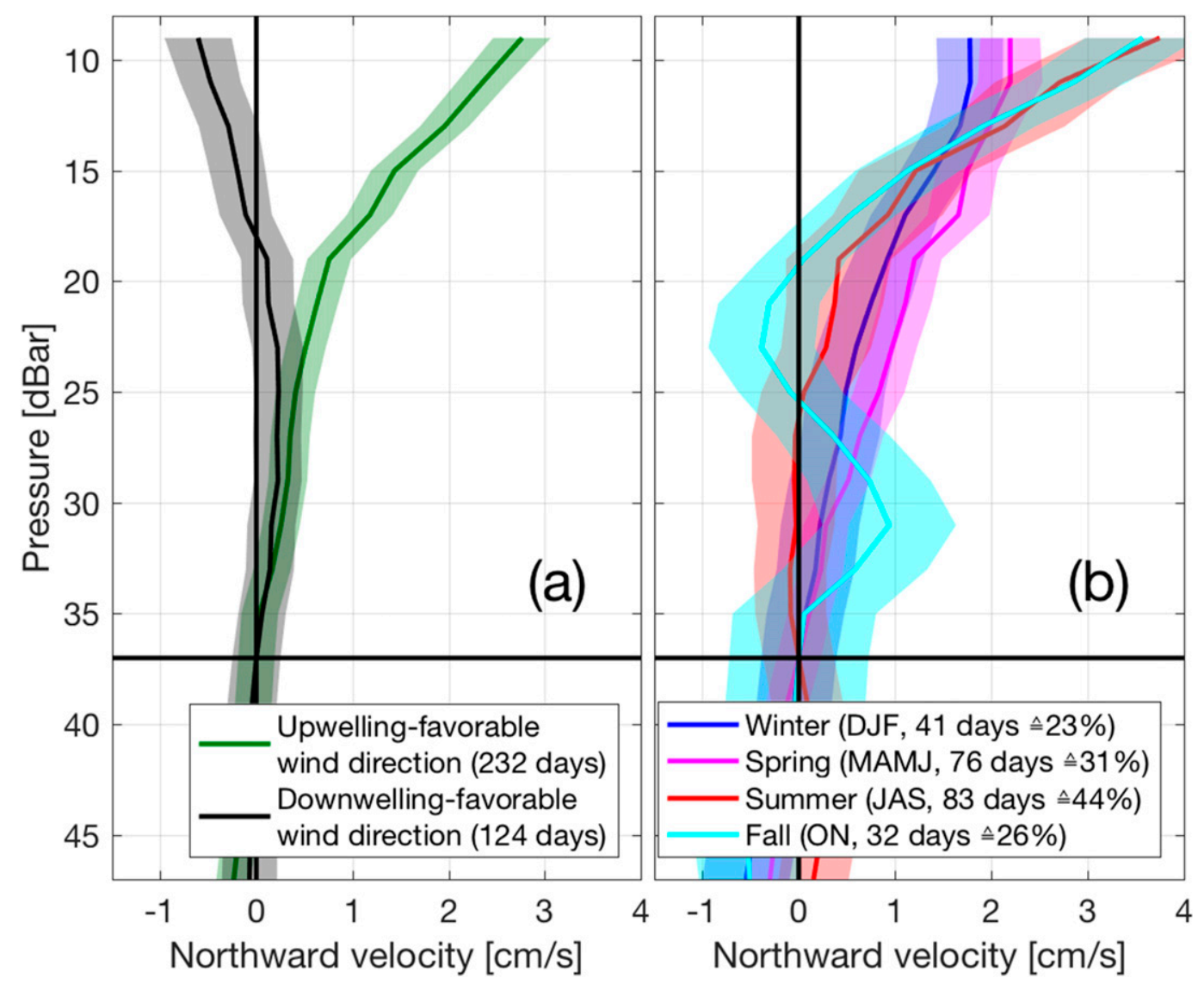

FIG. 14. (a) Profiles of northward (approximately cross-shore) velocity anomalies relative to their velocity at the Ekman layer depth ( $37 \mathrm{~m}$; horizontal black line) at the $\mathrm{M}_{2}$ mooring location averaged over all days with upwellingfavorable (northeasterly to southeasterly) wind direction (green) and over days with downwelling-favorable (northwesterly to southwesterly) wind direction (black). (b) Seasonal breakdown of the green profile in (a), again referenced to their velocity at the Ekman layer depth. Given in the legend are the months included in each season, the total number of upwelling-favorable wind days per season and what percentage of days per season that represents. Shading denotes one standard error of the mean.

anomaly reaching $0.6 \mathrm{~cm} \mathrm{~s}^{-1}$ in downwelling-favorable wind conditions. For depths below the Ekman layer, contributions of up- or downwelling circulations to cross-shore velocity profiles cannot easily be analyzed with the data at hand, because the shape of the profiles is governed by multiple factors, including other seasonal processes [e.g., advection or front displacement, as discussed in sections $4 \mathrm{~b}(1)$ and $4 \mathrm{~b}(3)]$. A dedicated modeling study may be able to verify indirect (upwelling related) wind effects on the deeper ocean velocity profiles.

A seasonal breakdown of cross-shore velocity profiles under upwelling-favorable conditions referenced to the Ekman layer depth is shown in Fig. 14b. During summer and fall, the offshore anomalies (indicative of upwelling) are strongest, reaching 3.7 and $3.6 \mathrm{~cm} \mathrm{~s}^{-1}$ at $9-\mathrm{m}$ depth, respectively. Note that the weight of the summer profile contributing to the mean is substantially greater than that of the fall profile (83 days of upwelling-favorable winds in summer compared to 32 days in fall). The change of direction of the fall profile between $\sim 20$ and $\sim 26 \mathrm{~m}$ indicates that some additional factor(s) play a role in shaping the profile. In winter and spring, the surface response to upwelling-favorable winds does not exceed $2.2 \mathrm{~cm} \mathrm{~s}^{-1}$. We thus argue that the discussed features of the velocity profiles as well as the doubling of the number of upwelling-favorable wind conditions during summer strengthen the upwelling hypothesis.

Upwelling signatures also manifest in shoaling of isopycnals at the front near the slope in summer, relative to the preceding winter (Fig. 15 shows this at the example of the 27.84 isopycnal). Upwelled water may explain the observed summertime colder water onshore of the front (Fig. 7e).

We conclude that the upwelling hypothesis is qualitatively supported by the ERA-Interim wind data, 


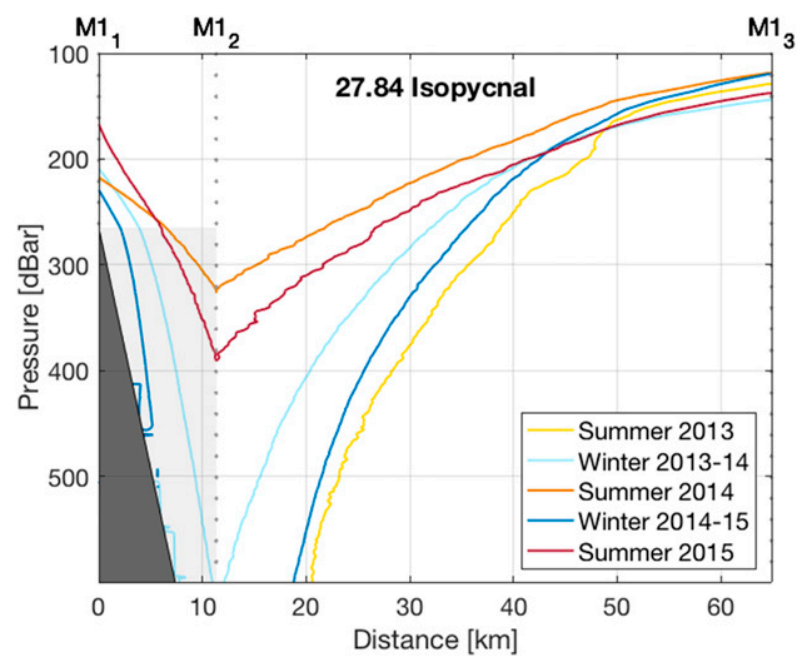

FIG. 15. Seasonally averaged position of the 27.84 isopycnal at the three onshore-most moorings. Dark gray shading marks the approximate position of the continental slope; light gray shading indicates area where isolines are due to extrapolation as the depth difference between the moorings does not allow for horizontal interpolation.

seasonal isopycnal pattern, and upper-ocean current observations, and is possibly an important driver for the lower temperatures close to the slope in summer. However, it cannot explain the large positive seasonal difference in temperature at the $\mathrm{M}_{3}$ mooring site (Fig. 7e). We also note that since upwelling is directly dependent on the large-scale atmospheric circulation, which is known to vary on interannual time scales as well as in response to sea ice loss (e.g., Overland and Wang 2010), the contribution of upwelling to the observed seasonality will change over time.

\section{3) FRONT DISPLACEMENT}

In addition to along-slope advection and upwelling, lateral displacement of the hydrographic front may be a factor in contributing to the seasonality observed in the USD. This relocation process can be linked to prevailing upwelling wind conditions, as has been observed, for example, by Houghton et al. (1994). They found that in the Middle Atlantic Bight, wind-driven upwelling events displace the local front onshore by about $20 \mathrm{~km}$ from its equilibrium position. Chapman (2000) explored the physical mechanisms defining shifts of the position of a front using an idealized model. The model simulates a surface-to-bottom front between a buoyant shelf current and a homogeneous ocean on a sloping topography. The practical applicability of this simple model has been demonstrated in a number of publications (e.g., Hetland and Signell 2005; Weingartner et al. 2005). Chapman (2000) showed that, in accordance with Wright (1989), the bottom attachment point-or depth-of the front can be approximated as follows:

$$
h_{0}=\left(2 U_{0} f / \epsilon g\right)^{1 / 2},
$$

with $U_{0}$ the alongshore transport at the front, $f$ the Coriolis parameter, $\epsilon=\Delta \rho / \rho_{0}$, the density anomaly across the front, and $g$ the gravitational acceleration. Note that the position of the front depends solely on the transport at the front and the density difference across it. Assuming that the front is located somewhere between the moorings $\mathrm{M} 1_{2}$ and $\mathrm{M}_{3}$, we can roughly estimate these variables: $U_{0}$ is approximated as the mean of the vertically integrated $(>750 \mathrm{~m})$ transports at $\mathrm{M}_{2}$ and $\mathrm{M}_{3}$ multiplied by the distance between the moorings. Similarly, $\epsilon$ is calculated using the difference of vertically averaged density between these moorings (Table 1). Table 2 shows estimates for the front attachment depth (i.e., its position on the slope) dependent on either constant or seasonally-averaged density and transport. It emerges that seasonally changing density gradients counteract the effect of seasonally changing transports on the front attachment depth, but changes in transport are dominant in defining the observed seasonal movement of the front. The estimated front attachment depth $h_{0}$ would thus be about $100 \mathrm{~m}$ shallower in summer $(\sim 608 \mathrm{~m})$ compared to winter $(\sim 704 \mathrm{~m})$ (Table 2) (both estimates are shallower than the expected $\sim 750-\mathrm{m}$ depth of the front and are likely due to the idealized approach). At the eastern EB continental slope, a 100-m depth difference translates to a cross-slope displacement of about $4 \mathrm{~km}$.

This seasonal movement of the front potentially contributes to the seasonal cycle observed in the USD. Reduced alongshore transport in summer forces the front to move farther onshore, bringing warmer waters from the offshore $\mathrm{AW}$ core closer to the $\mathrm{M} 1_{3}$ mooring.

TABLE 1. Values for $U_{0}$, the alongshore transport at the front and $\epsilon=\Delta \rho / \rho_{0}$, the density anomaly across the front. Calculations were made using data from moorings $\mathrm{M}_{2}$ and $\mathrm{M}_{3}$ integrated over the top $750 \mathrm{~m}$ of the water column (see text for details). Overbars denote all-time (two year) averages while primes indicate seasonal averages.

\begin{tabular}{lcccc}
\hline \hline & $\epsilon^{\prime}$ & $U_{0}^{\prime}$ & $\bar{\epsilon}$ & $\overline{U_{0}}$ \\
\hline Summer & $1.41 \times 10^{-4}$ & $1.8 \times 10^{6} \mathrm{~m}^{3} \mathrm{~s}^{-1}$ & $1.57 \times 10^{-4}$ & $2.18 \times 10^{6} \mathrm{~m}^{3} \mathrm{~s}^{-1}$ \\
Winter & $1.73 \times 10^{-4}$ & $2.96 \times 10^{6} \mathrm{~m}^{3} \mathrm{~s}^{-1}$ & & \\
\hline
\end{tabular}


TABLE 2. Front depth $h_{0}$ [Eq. (2)], calculated using different combinations of transport and density anomaly averages.

\begin{tabular}{lrrr}
\hline \hline & $\bar{\epsilon}, U_{0}^{\prime}$ & $\epsilon^{\prime}, \overline{U_{0}}$ & $\epsilon^{\prime}, U_{0}^{\prime}$ \\
\hline Summer $h_{0}$ & $576 \mathrm{~m}$ & $783 \mathrm{~m}$ & $608 \mathrm{~m}$ \\
Winter $h_{0}$ & $739 \mathrm{~m}$ & $707 \mathrm{~m}$ & $704 \mathrm{~m}$ \\
$\Delta h_{0}$ & $-163 \mathrm{~m}$ & $76 \mathrm{~m}$ & $-96 \mathrm{~m}$ \\
\hline
\end{tabular}

The effect of this displacement on measurements at moorings onshore of the front $\left(\mathrm{M} 1_{1}\right.$ and $\left.\mathrm{M} 1_{2}\right)$ depends on the shape of the front. Since the moored observations cannot fully resolve it (the depth difference between $\mathrm{M} 1_{1}$ and $\mathrm{M} 1_{2}$ is $\sim 500 \mathrm{~m}$ ), there are two possibilities: either the front is V shaped (Gill 1973), as indicated by the isopycnals in Figs. 7a-d and Fig. 15, comprising a "wedge" of cold, fresh, and less dense water in its center, or it is simply retrograde (sloping down toward the continental slope), as is hinted by repeat hydrographic sections (not shown). In the first case, the summertime onshore moving front may bring the cold water within the wedge toward $\mathrm{M} 1_{1}$ and $\mathrm{M} 1_{2}$ and thus contribute to the observed seasonality; in the latter case, the seasonality onshore of the front cannot be explained by its seasonal displacement.

With the data at hand, we cannot draw final conclusions as to the seasonal movement of the front. A denser array of moorings in this region is needed in order to obtain direct observational evidence. However, we hypothesize that, owing to the relatively small expected lateral displacement, frontal movement is arguably less important than upwelling and advection in shaping the seasonality in the USD.

\section{4) ISOPYCNAL DISPLACEMENT IN THE COLD HALOCLINE LAYER}

The origin of isopycnal displacement in the CHL of the USD as deduced from the seasonal salinity signal is too widespread (at least $60 \mathrm{~km}$ and across the front) and deep (down to $\sim 100 \mathrm{~m}$ ) to be a direct consequence of any of the aforementioned mechanisms. Instead, we refer to the following section where the isopycnal displacement in the LSD is discussed in detail. Even though the signal in the USD is located in the CHL as opposed to the LHW in the LSD, it is likely that both signals have a similar origin.

\section{c. Lower-slope domain}

There are several potential contributors to the observed seasonal displacement of isopycnal surfaces in the LSD halocline. We argue that along-slope advection cannot play the dominant role in this seasonal cycle, because the intensity and direction of currents varies substantially across the LSD (Fig. 12b). This makes it

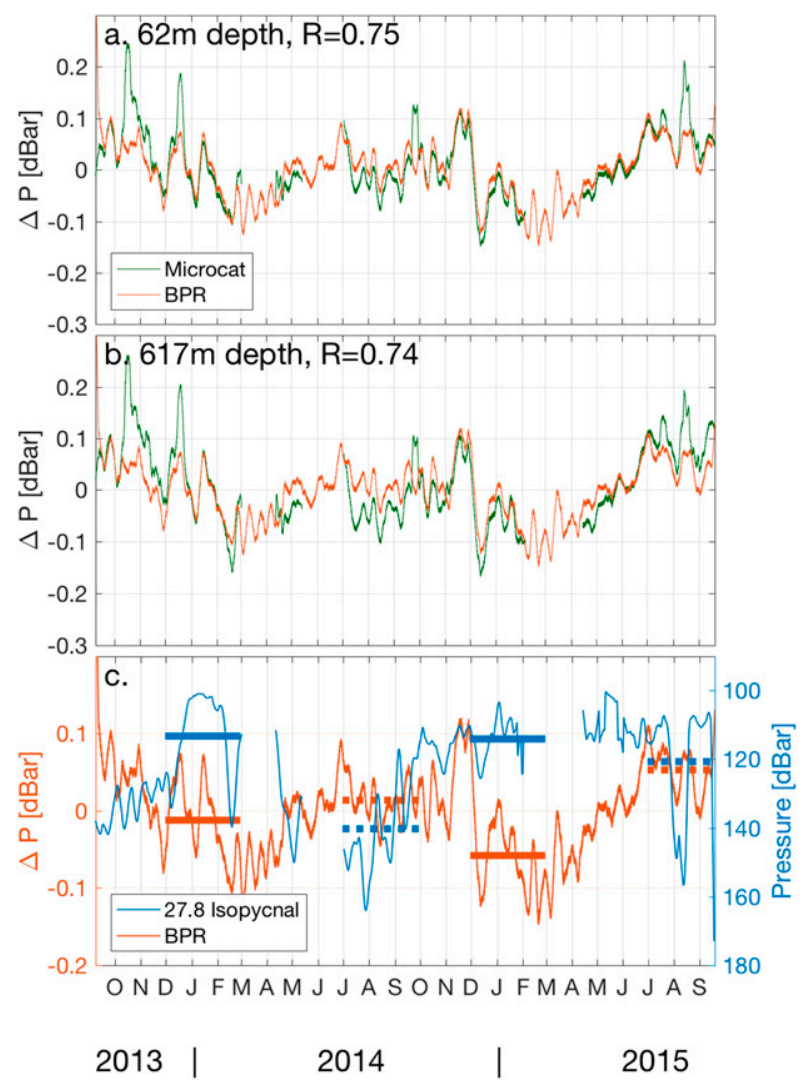

FIG. 16. (a),(b) Smoothed (using 7-day running mean) time series of pressure anomalies from the BPR at 2720-m depth and MicroCATs at approximately $62-$ and $617-\mathrm{m}$ depth at the $\mathrm{M} 1_{4}$ mooring. " $\mathrm{R}$ " denotes the correlation coefficient between the BPR and MicroCATs. (c) Time series of BPR pressure anomaly and 27.8 isopycnal pressure, both smoothed with a 7-day running mean. Thick horizontal solid and dotted lines mark winter and summer averages. Note that in the time series of MicroCAT pressures and isopycnal depth, three "dive events" are removed (March-April 2014, May-July 2014, and February-April 2015). During these events, the mooring was presumably tilted by currents, resulting in instruments effectively measuring several meters deeper than their intended depth.

difficult to explain the observed in-phase pattern of the seasonal signal at all moorings with lateral advection (Figs. 7e,f).

Alternatively, the observed isopycnal displacement may be linked to seasonal variations of sea level height. Local sea level variations are evaluated using a twoyear-long (2013-15) bottom pressure record from the Bottom Pressure Recorder (BPR) deployed at the M1 mooring at 2720-m depth. Complementing the BPR are pressure measurements provided by five MicroCATs distributed between $\sim 600$ and $\sim 62 \mathrm{~m}$ at the mooring (Fig. 3). The bottom pressure shows a seasonal cycle with higher pressure in summer compared to winter with a seasonal difference of $0.068 \mathrm{dbar}$ (Fig. 16c). 
A similar seasonality is observed at all five MicroCAT pressure records as evidenced by high correlations ( $R=0.69-0.74)$ and the same range of seasonal variations (exemplarily shown for the shallowest and deepest instruments in Figs. 16a,b). This suggests that the observed pressure changes originate in the upper-60-m layer and can be caused either by seasonal density variations in this layer or by sea level change. Estimates based on the $\mathrm{M}_{6} 6$ upper-ocean array data-(nearest neighbor) extrapolated to the surface-show that average seasonal density variability $\left(\Delta \sigma=0.03 \mathrm{~kg} \mathrm{~m}^{-3}\right)$ can only account for $0.002 \mathrm{dbar}$ of seasonal pressure change, over one order of magnitude less than the observed seasonal change at the BPR. Thus, we conclude that seasonal pressure variations are caused by sea level changes, with elevated sea level (higher pressure) in summer and depressed sea level (lower pressure) in winter, with 0.068 -dbar pressure difference. This is equivalent to about $6.8 \mathrm{~cm}$ of seasonal sea level change.

Let us now compare the seasonal changes of sea level and isopycnal displacements. We first note the out-ofphase (i.e., opposed) displacement of isopycnals compared to the seasonal change of sea level, with 36-m elevation of isopycnal surfaces in winter relative to summer [section $3 \mathrm{a}(3)]$. This pattern follows the well-established baroclinic response of density interfaces to sea level variations (e.g., Chaen and Wyrtki 1981). The baroclinic response can be further analyzed using theoretical considerations. For an idealized nonrotating two-layer ocean, the following expression was derived (e.g., Gill 1982):

$$
\eta / h \approx-g^{\prime} H_{2} / g H,
$$

where the ratio between the surface displacement $\eta$ and the interface displacement $h$ is approximated as a function of reduced gravity $g^{\prime}=g\left(\rho_{2}-\rho_{1}\right) / \rho_{2}=$ $0.002 \mathrm{~m} \mathrm{~s}^{-2}$, with $\rho_{1}=1027.68 \mathrm{~kg} \mathrm{~m}^{-3}$ and $\rho_{2}=$ $1027.96 \mathrm{~kg} \mathrm{~m}^{-3}$ the densities of the upper layer and lower layer, respectively (derived from observations at the $\mathrm{M} 1_{4}$ mooring); the equilibrium thickness of the lower layer $H_{2}=2590 \mathrm{~m}$; gravity $g=9.81 \mathrm{~m} \mathrm{~s}^{-2}$; and the total ocean depth $H=2720 \mathrm{~m}$. Using this expression, the expected sea level change needed to explain that the observed $36-\mathrm{m}$ isopycnal displacement is estimated to be $7 \mathrm{~mm}$, or about one order of magnitude less than observed via the BPR. Thus, while observations and theoretical estimates qualitatively agree with out-ofphase displacements of sea level and the interface layer, quantitatively they differ substantially. This misfit is probably due to the high degree of simplification involving the theoretical considerations that may not adequately represent the observed phenomenon. Further analysis is needed in order to understand this

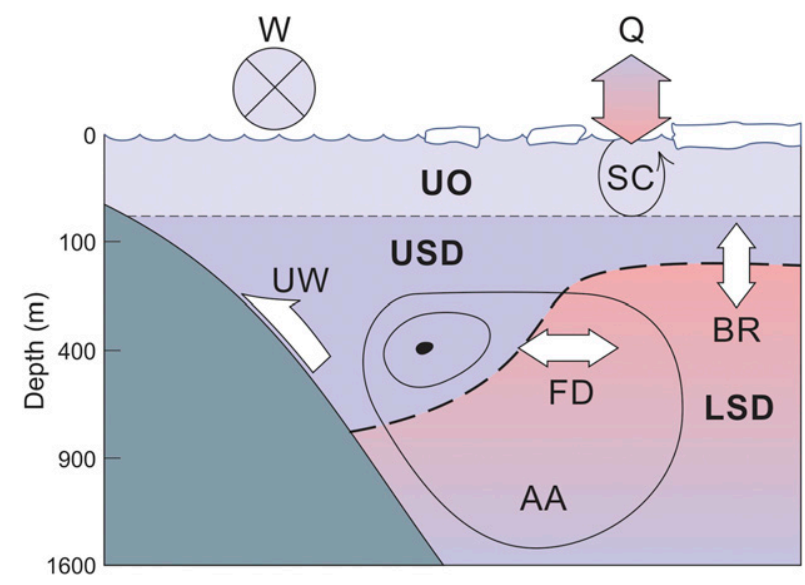

FIG. 17. Sketch summarizing the different mechanisms of seasonality discussed in this study. UO: seasonal convection (SC) due to brine rejection, wind mixing, and surface heat fluxes (Q). USD: upwelling (UW) due to summertime easterly winds (W), alongstream advection (AA) within the ACBC, and front displacement (FD). LSD: isopycnal displacement as baroclinic response (BR) to seasonal sea level change.

complex relationship between seasonal sea level and isopycnal displacements.

\section{Concluding remarks}

The Laptev Sea continental slope area shows a complex pattern of seasonality. The individual cycles and their hypothesized drivers can be summarized as follows (Fig. 17):

- Upper ocean: wintertime cooling and salinification due to sea ice formation impacts the upper $\sim 80 \mathrm{~m}$ of the water column.

- Upper-slope domain (USD) in the vicinity of the hydrographic front: signal advection within the $\mathrm{ACBC}$, summertime wind-driven upwelling (in recent years), and cross-slope displacement of the front due to seasonal changes in alongshore dynamics may play a role in the temperature-dominated seasonality down to $\sim 600 \mathrm{~m}$.

- Lower-slope domain (LSD) halocline: Seasonality is caused by a vertical displacement of isopycnals of up to $36 \mathrm{~m}$. A baroclinic response to seasonal sea level changes is a potential driver behind this seasonality. With the data at hand we cannot pinpoint the final mechanism responsible for the sea level variations.

Arguably, the most striking discovery is that of large temperature seasonality in the USD. A seasonal difference of up to $1.4^{\circ} \mathrm{C}$ implies that a substantial shift of heat across the slope may take place with possible impacts on local dynamics, air-sea interactions, and sea 
ice formation, making it imperative to investigate the extent to which the three potential drivers presented in this study contribute to the observed cycle and how persistent they are on interannual time scales. Furthermore, the large temperature variability, combined with the overall warming trend in this region, may point toward increasing temperature's role in determining seawater density (see Carmack 2007; Timmermans and Jayne 2016).

The seasonality of the LSD halocline at $\mathrm{M}_{4}$ is the signal documented by Dmitrenko et al. (2009) and Polyakov et al. (2017) and found to have increased in recent years. This implies that the associated vertical displacement of isopycnals may also be increasing. Further research is needed to investigate whether extensive seasonal variability within the halocline increases mixing and thus contributes to its ongoing erosion and facilitate convection (thus representing a positive feedback), which was described as "Atlantification" of the Arctic Ocean by Polyakov et al. (2017). They observed an increased upward heat flux from the AW into the upper ocean with direct consequences for sea ice formation and a potential for impacting atmosphere-ocean exchange and the Arctic climate. Because such convection also involves other ocean properties, such as nutrients and components of the carbon cycle, it will likewise impact Arctic ecosystems (Bluhm et al. 2015). To make reasonable future projections, it is essential to fully understand the role of seasonality in this process.

While the NABOS mooring array enabled us to identify, for the first time, a complex pattern of seasonality in the eastern Eurasian Basin, its design is not ideal for a detailed analysis of each seasonal cycle. For a quantitative study, the spacing between moorings in the USD must be narrower to fully resolve the seasonal movement and shape of the front. Moorings with instruments reaching up closer to the surface are required to capture SML hydrography. Nevertheless, a set of plausible drivers of seasonality have been identified that may provide a base for further observational and modeling efforts seeking to better understand the variability of the eastern Arctic Ocean and the implications for global climate.

Acknowledgments. The mooring- and ship-based oceanographic observations in the eastern EB were conducted within the framework of the NABOS project, with support from NSF (Grants 1203473, 1249133, and 1203146) and the National Oceanic and Atmospheric Administration (Grants NA150AR4310155 and NA150AR4310156). Vladimir Ivanov acknowledges funding from the Ministry of Education and Science of the Russian Federation (Project RFMEFI61617X0076). We thank two anonymous reviewers for providing very insightful comments and suggestions that helped to improve the manuscript.

\section{REFERENCES}

Aagaard, K., 1989: A synthesis of the Arctic Ocean circulation. Rapp. P.-V. Reun. Cons. Int. Explor. Mer, 188, 11-22.

_, L. K. Coachman, and E. Carmack, 1981: On the halocline of the Arctic Ocean. Deep-Sea Res., 28A, 529-545, https:// doi.org/10.1016/0198-0149(81)90115-1.

Aksenov, Y., V. V. Ivanov, A. J. G. Nurser, S. Bacon, I. V. Polyakov, A. C. Coward, A. C. Naveira-Garabato, and A. BeszczynskaMoeller, 2011: The Arctic Circumpolar Boundary Current. J. Geophys. Res., 116, C09017, https://doi.org/10.1029/2010JC006637.

Alkire, M. B., I. Polyakov, R. Rember, A. Pnyushkov, V. Ivanov, and I. Ashik, 2017: Combining physical and geochemical methods to investigate lower halocline water formation and modification along the Siberian continental slope. Ocean Sci., 13, 983-995, https://doi.org/10.5194/os-13-983-2017.

Atkinson, D. E., 2005: Observed storminess patterns and trends in the circum-Arctic coastal regime. Geo-Mar. Lett., 25, 98-109, https://doi.org/10.1007/s00367-004-0191-0.

Barry, R. G., M. C. Serreze, J. A. Maslanik, and R. H. Preller, 1993: The Arctic sea ice-climate system: Observations and modeling. Rev. Geophys., 31, 397-422, https://doi.org/10.1029/ 93RG01998.

Bauch, D., S. Torres-Valdes, I. Polyakov, A. Novikhin, I. Dmitrenko, J. McKay, and A. Mix, 2014: Halocline water modification and along-slope advection at the Laptev Sea continental margin. Ocean Sci., 10, 141-154, https://doi.org/ 10.5194/os-10-141-2014.

, E. Cherniavskaia, and L. Timokhov, 2016: Shelf basin exchange along the Siberian continental margin: Modification of Atlantic Water and Lower Halocline Water. Deep-Sea Res. I, 115, 188-198, https://doi.org/10.1016/j.dsr.2016.06.008.

Bluhm, B. A., K. N. Kosobokova, and E. C. Carmack, 2015: A tale of two basins: An integrated physical and biological perspective of the deep Arctic Ocean. Prog. Oceanogr., 139, 89-121, https://doi.org/10.1016/j.pocean.2015.07.011.

Carmack, E. C., 2007: The alpha/beta ocean distinction: A perspective on freshwater fluxes, convection, nutrients and productivity in high-latitude seas. Deep-Sea Res. II, 54, 2578-2598, https://doi.org/10.1016/j.dsr2.2007.08.018.

Chaen, M., and K. Wyrtki, 1981 : The $20^{\circ} \mathrm{C}$ isotherm depth and sea level in the western equatorial Pacific. J. Oceanogr. Soc. Japan, 37, 198-200, https://doi.org/10.1007/BF02309057.

Chapman, D. C., 2000: Boundary layer control of buoyant coastal currents and the establishment of a shelfbreak front. J. Phys. Oceanogr., 30, 2941-2955, https://doi.org/ 10.1175/1520-0485(2001)031<2941:BLCOBC>2.0.CO;2.

Coachman, L. K., and C. A. Barnes, 1963: The movement of Atlantic Water in the Arctic Ocean. Arctic, 16, 8-16, https:// doi.org/10.14430/arctic3517.

Dee, D. P., and Coauthors, 2011: The ERA-Interim reanalysis: Configuration and performance of the data assimilation system. Quart. J. Roy. Meteor. Soc., 137, 553-597, https://doi.org/ 10.1002/qj.828.

Dmitrenko, I. A., I. V. Polyakov, S. A. Kirillov, L. A. Timokhov, H. L. Simmons, V. V. Ivanov, and D. Walsh, 2006: Seasonal variability of Atlantic Water on the continental slope of the Laptev Sea during 2002-2004. Earth Planet. Sci. Lett., 244, 735-743, https://doi.org/10.1016/j.epsl.2006.01.067.

, and Coauthors, 2009: Seasonal modification of the Arctic Ocean intermediate water layer off the eastern Laptev Sea continental shelf break. J. Geophys. Res., 114, C06010, https:// doi.org/10.1029/2008JC005229. 
_- and Coauthors, 2014: Heat loss from the Atlantic Water layer in the northern Kara Sea: Causes and consequences. Ocean Sci., 10, 719-730, https://doi.org/10.5194/os-10-719-2014.

Ekman, V. W., 1905: On the influence of the Earth's rotation on ocean-currents. Ark. Mat. Astron. Fys., 2, 1-52.

Fer, I., A. K. Peterson, A. Randelhoff, and A. Meyer, 2017: Onedimensional evolution of the upper water column in the Atlantic sector of the Arctic Ocean in winter. J. Geophys. Res. Oceans, 122, 1665-1682, https://doi.org/10.1002/2016JC012431.

Gill, A. E., 1973: Circulation and bottom water production in the Weddell Sea. Deep-Sea Res. Oceanogr. Abstr., 20, 111-140, https://doi.org/10.1016/0011-7471(73)90048-X.

—_, 1982: Atmosphere-Ocean Dynamics. Academic Press, $662 \mathrm{pp}$.

Hetland, R. D., and R. P. Signell, 2005: Modeling coastal current transport in the Gulf of Maine. Deep-Sea Res. II, 52, 2430 2449, https://doi.org/10.1016/j.dsr2.2005.06.024.

Houghton, R. W., C. N. Flagg, and L. J. Pietrafesa, 1994: Shelfslope water frontal structure, motion and eddy heat flux in the southern Middle Atlantic Bight. Deep-Sea Res. II, 41, 273-306, https://doi.org/10.1016/0967-0645(94)90024-8.

Ivanov, V. V., and Coauthors, 2009: Seasonal variability in Atlantic Water off Spitsbergen. Deep-Sea Res. I, 56, 1-14, https://doi.org/10.1016/j.dsr.2008.07.013.

Janout, M. A., J. Hölemann, and T. Krumpen, 2013: Cross-shelf transport of warm and saline water in response to sea ice drift on the Laptev Sea shelf. J. Geophys. Res. Oceans, 118, 563576, https://doi.org/10.1029/2011JC007731.

_ , and Coauthors, 2015: Kara Sea freshwater transport through Vilkitsky Strait: Variability, forcing, and further pathways toward the western Arctic Ocean from a model and observations. J. Geophys. Res. Oceans, 120, 4925-4944, https://doi.org/ 10.1002/2014JC010635.

Lique, C., and M. Steele, 2012: Where can we find a seasonal cycle of the Atlantic Water temperature within the Arctic Basin? J. Geophys. Res., 117, C03026, https://doi.org/10.1029/2011JC007612.

Maslanik, J. A., C. Fowler, J. Stroeve, S. Drobot, J. Zwally, D. Yi, and W. Emery, 2007: A younger, thinner Arctic ice cover: Increased potential for rapid, extensive sea-ice loss. Geophys. Res. Lett., 34, L24501, https://doi.org/10.1029/2007GL032043.

Monterey, G. I., and S. Levitus, 1997: Climatological cycle of mixed layer depth in the World Ocean. NOAA Atlas NESDIS 14, 5 pp.

Overland, J. E., and M. Wang, 2010: Large-scale atmospheric circulation changes are associated with the recent loss of Arctic sea ice. Tellus, 62A, 1-9, https://doi.org/10.1111/ j.1600-0870.2009.00421.x.

Pnyushkov, A. V., I. V. Polyakov, V. V. Ivanov, Y. Aksenov, A. C. Coward, M. Janout, and B. Rabe, 2015: Structure and variability of the boundary current in the Eurasian Basin of the Arctic Ocean. Deep-Sea Res. I, 101, 80-97, https://doi.org/ 10.1016/j.dsr.2015.03.001.
_- and Coauthors, 2018: Heat, salt, and volume transports in the eastern Eurasian Basin of the Arctic Ocean, from two years of mooring observations. Ocean Sci. Discuss., https://doi.org/ 10.5194/os-2018-36.

Polyakov, I. V., 1999: Modeling of the seasonal variability in the Arctic Ocean. Oceanology, 39, 446-456.

—, A. Y. Proshutinsky, and M. A. Johnson, 1999: Seasonal cycles in two regimes of Arctic climate. J. Geophys. Res., 104, 25 76125 788, https://doi.org/10.1029/1999JC900208.

— A. V. Pnyushkov, R. Rember, L. Padman, E. C. Carmack, and J. M. Jackson, 2013: Winter convection transports Atlantic Water heat to the surface layer in the eastern Arctic Ocean. J. Phys. Oceanogr., 43, 2142-2155, https://doi.org/ 10.1175/JPO-D-12-0169.1.

_ ice loss in the Eurasian Basin of the Arctic Ocean. Science, 356, 285-291, https://doi.org/10.1126/science.aai8204.

Rudels, B., A.-M. Larsson, and P.-I. Sehlstedt, 1991: Stratification and water mass formation in the Arctic Ocean: Some implications for the nutrient distribution. Polar Res., 10, 19-32, https://doi.org/10.3402/polar.v10i1.6724.

— E. P. Jones, L. G. Anderson, and G. Kattner, 1994: On the intermediate depth waters of the Arctic Ocean. The Polar Oceans and Their Role in Shaping the Global Environment, Geophys. Monogr., Vol. 188, Amer. Geophys. Union, 33-46.

$\longrightarrow$, L. G. Anderson, and E. P. Jones, 1996: Formation and evolution of the surface mixed layer and halocline of the Arctic Ocean. J. Geophys. Res., 101, 8807-8821, https://doi.org/ 10.1029/96JC00143.

—, R. D. Muench, J. Gunn, U. Schauer, and H. J. Friedrich, 2000: Evolution of the Arctic Ocean boundary current north of the Siberian shelves. J. Mar. Syst., 25, 77-99, https://doi.org/ 10.1016/S0924-7963(00)00009-9.

Timmermans, M.-L., and S. R. Jayne, 2016: The Arctic Ocean spices up. J. Phys. Oceanogr., 46, 1277-1284, https://doi.org/ 10.1175/JPO-D-16-0027.1.

Timofeev, V. T., 1960: Water Masses of the Arctic Basin. Gidrometeoizdat, 190 pp.

Timokhov, L., and F. Tanis, 1997: Environmental Working Group Joint U.S.-Russian Atlas of the Arctic Ocean, version 1. National Snow and Ice Data Center, https://doi.org/10.7265/ N5H12ZX4.

Torrence, C., and G. P. Compo, 1998: A practical guide to wavelet analysis. Bull. Amer. Meteor. Soc., 79, 61-78, https://doi.org/ 10.1175/1520-0477(1998)079<0061:APGTWA > 2.0.CO;2.

Weingartner, T. J., S. L. Danielson, and T. C. Royer, 2005: Freshwater variability and predictability in the Alaska Coastal Current. Deep-Sea Res. II, 52, 169-191, https://doi.org/10.1016/ j.dsr2.2004.09.030.

Wright, D. G., 1989: On the alongshelf evolution of an idealized density front. J. Phys. Oceanogr., 19, 532-541, https://doi.org/ 10.1175/1520-0485(1989)019<0532:OTAEOA > 2.0.CO;2. 